Portland State University

PDXScholar

\title{
Examining the Effect of Case and Trial Factors on Defense Attorneys' Plea Decision-Making
}

Kelsey S. Henderson

Portland State University, kelsey.henderson@pdx.edu

Follow this and additional works at: https://pdxscholar.library.pdx.edu/ccj_fac

Part of the Criminology and Criminal Justice Commons

Let us know how access to this document benefits you.

\section{Citation Details}

Henderson, K. S. (2020). Examining the effect of case and trial factors on defense attorneys' plea decision-making. Psychology, Crime \& Law, 1-26. https://doi.org/10.1080/1068316X.2020.1805744

This Pre-Print is brought to you for free and open access. It has been accepted for inclusion in Criminology and Criminal Justice Faculty Publications and Presentations by an authorized administrator of PDXScholar. Please contact us if we can make this document more accessible: pdxscholar@pdx.edu. 
PRE-PRINT Henderson, K. S. (forthcoming). Examining the Effect of Case and Trial Factors on Defense Attorneys' Plea Decision-making. Psychology, Crime \& Law. https://doi.org/10.1080/1068316X.2020.1805744

\begin{abstract}
Defense attorneys are attuned to the defendant's likelihood of conviction at trial, based on the strength of the evidence, in forming their plea decisions. A higher threshold for conviction (i.e., unanimous jury verdict rule versus majority rule), could affect defense attorneys' willingness to take cases to trial. In this study, we examined defense attorney decision-making by presenting defense attorneys with a hypothetical case summary in which the jury verdict rule was unanimous versus majority rule (experiment one, $N=82$ ), and the strength of the evidence was weak versus strong (experiment two, $N=81$ ). In experiment one, there was no direct or indirect effect of jury verdict rule on plea decision-making. Rather, defense attorney estimates of the defendant's likelihood of conviction predicted plea decisions; defense attorneys who perceived a higher likelihood of conviction were more likely to recommend plea bargaining than those who perceived a lower likelihood of conviction. In experiment two, strength of evidence influenced a number of defense attorney decisions. Defense attorneys in strong evidence conditions were more likely to recommend plea bargaining, rated the defendant's likelihood of conviction higher, and their probability of winning at trial lower than those in weak evidence conditions.
\end{abstract}

Keywords: plea bargaining; jury verdict rule; strength of evidence; defense attorneys; Shadow of Trial

Word count: 10,134

Data Availability Statement: The data that supports the findings of this study are available from the corresponding author, $\mathrm{KH}$, upon reasonable request. 
PRE-PRINT Henderson, K. S. (forthcoming). Examining the Effect of Case and Trial Factors on Defense Attorneys' Plea Decision-making. Psychology, Crime \& Law. https://doi.org/10.1080/1068316X.2020.1805744

Examining the Effect of Case and Trial Factors on Defense Attorneys' Plea Decision-making The issue of jury unanimity is as old as the U.S. Constitution. James Madison's first draft of the $6^{\text {th }}$ Amendment called for unanimous juries, however, the clause- "requisite of unanimity for conviction" - was removed by the Senate before passing (as cited in Ramos v. Louisiana, 2020). More than a century later, this clause was extended to federal courts, but not state courts (Johnson v. Louisiana, 1972; Apodaca v. Oregon, 1972); nevertheless, 49 states require a unanimous verdict decision in felony cases. In April of 2020, the United States Supreme Court (USSC) extended unanimity to state trials for serious offenses (Ramos v. Louisiana, 2020), carrying implications for the sole remaining state allowing for majority rule - Oregon.

In the majority opinion, the Court interpreted that the "text and structure" of the $6^{\text {th }}$ Amendment "carries with it some meaning about the content and requirements of a jury trial", which the Court has interpreted throughout history to mean unanimity (Ramos v. Louisiana, 2020, p. 1). The Court, ultimately finding in the Ramos decision that if the $6^{\text {th }}$ Amendment is incorporated by the states in the $14^{\text {th }}$ Amendment, then the $6^{\text {th }}$ Amendment's requirement for unanimity in federal trials must extend to states as well. The Court discussed how the precedent allowing for non-unanimous verdicts in state trials was flawed (Apodaca v. Oregon, 1972), and a ruling in favor of Louisiana would encourage other states to relax their unanimity requirement. In early May 2020, the USSC granted cert in Edwards v. Vannoy (2020), which questions if the Ramos decision applies retroactively (cases that are final on direct review and those currently on federal collateral review). Thus, the issue of jury unanimity and implications for will continue on through the 2020 USSC term.

In the United States, $94 \%$ of felony convictions occur in state courts, and the majority of those defendants pleaded guilty (95\%; Durose \& Langan, 2007). In forming the decision of 
PRE-PRINT Henderson, K. S. (forthcoming). Examining the Effect of Case and Trial Factors on Defense Attorneys' Plea Decision-making. Psychology, Crime \& Law. https://doi.org/10.1080/1068316X.2020.1805744

whether to recommend the defendant accept a guilty plea, defense attorneys are attuned to the defendant's likelihood of conviction at trial (McAllister \& Bregman, 1986a). Conviction is more likely with a majority rule jury compared to a unanimous jury (Buckhout, Weg, Reilly, \& Frohboese, 1977), and estimates suggest that in Oregon, $40 \%$ of cases that went to trial included a non-unanimous verdict on at least one count (Oregon Office of Public Defense Services, 2009). These same defendants may or may not have been convicted if they were prosecuted in federal courts or any other state in the U.S. (Kaplan \& Saack, 2016). A shift in the court's verdict rule could influence defense attorneys' estimation of trial outcomes and have implications for the legal system, specifically plea bargaining.

In forming plea decisions, defense attorneys ask the question of whether a case is "triable" (considering the risks). Under the Shadow of Trial framework (more below), the defendant's likelihood of conviction based on the strength of the evidence is one of the key variables that weighs into this equation. In short, there is a connection between expected outcomes at trial and willingness to plea bargaining. Moving the threshold for conviction higher (i.e., from majority rule to unanimous), could make defense attorneys less willing to plea bargain (and rather, more likely to take cases to trial). While research has explored the effects of verdict rule on jury deliberation and trial outcomes, it has not examined how verdict rule affects plea decisions. In a series of experiments, we examine how the strength of evidence and jury verdict rule affect defense attorneys' decisions.

\section{Juries and Verdict Rules}

Majority decisions are common to the courts; many states use a majority rule decision in civil trials (Larsen, 2002), and 22 states have laws dictating how to proceed if a jury cannot reach a unanimous sentencing verdict in death penalty cases (Death Penalty Information Center, 2018). 
PRE-PRINT Henderson, K. S. (forthcoming). Examining the Effect of Case and Trial Factors on Defense Attorneys' Plea Decision-making. Psychology, Crime \& Law. https://doi.org/10.1080/1068316X.2020.1805744

In Johnson and Apodaca, the Court addressed whether case outcomes would have differed had unanimity been the rule (as opposed to majority). The Justices contemplated if the viewpoints of all jurors had been considered and whether the minority's opinion would be considered if not needed to reach a consensus. Several assumptions were made about juror behavior. First, that the majority would not impose its ruling on the minority as long as the minority's opinion is wellreasoned. Second, that deliberation will not end when enough votes have been made for the required majority (Johnson v. Louisiana, 1977). Furthermore, that the quality of the deliberation or reliability of the final verdict would not be hindered by a majority rule decision (Apodaca $v$. Oregon, 1972). Many of these assumptions have been challenged by empirical work on jury decision-making since the time of these decisions.

\section{Implications of Jury Verdict Rules}

In the Johnson and Apodaca decisions (1972), it was assumed that deliberation would not end when enough votes were tallied for a required majority and that the majority would not impose its ruling on the minority as long as the minority's opinion was well-reasoned. Research has found that majority rule juries do stop deliberating after the required quorum was reached (Nemeth, 1977). As one juror stated to a dissenting holdout when the necessary majority quorum was reached, "All right, no offense, but we are going to ignore you" (Diamond, Rose, \& Murphy, 2006, pg. 216). Overall, majority rule juries were less likely to perceive their fellow jurors as open-minded, that all jurors' views were considered (Diamond et al., 2006), that they agreed with the verdict, and that justice had been done compared to unanimous juries (Nemeth, 1977).

Another assumption was that the quality of the deliberation would not be hindered by a non-unanimous rule (Apodaca et al. v. Oregon, 1972). There is research to suggest that nonunanimous juries are likely to vote within the first 10 minutes of deliberation (Bornstein \& 
PRE-PRINT Henderson, K. S. (forthcoming). Examining the Effect of Case and Trial Factors on Defense Attorneys' Plea Decision-making. Psychology, Crime \& Law. https://doi.org/10.1080/1068316X.2020.1805744

Greene, 2017), deliberate for a shorter period of time, and reach a decision quicker than unanimous juries (Davis, Kerr, Atkin, Holt, \& Meek, 1975; Kerr, Atkin, Stasser, Meek, Holt, \& Davis, 1976). Lastly, it was assumed that the reliability of the verdict would not be affected by the decision rule (Apodaca et al. v. Oregon, 1972). According to Saks and Ostrom's model (1975), unanimous juries should convict less often than those using majority rule, and the majority of research supports this model. In one study, majority rule juries convicted three times as often as unanimous juries (Buckhout et al., 1977). In examining the effects of deliberation, majority rule produced a shift pre-deliberation to post-deliberation towards a more severe verdict, and unanimous towards a less severe verdict (Buckhout et al., 1977). Overall, judgments from non-unanimous juries are perceived as "less predictable and accurate" (Bornstein \& Greene, 2017, p. 81), and more likely to result in a conviction (Friedman, 1972).

\section{Theoretical Motivation: Plea Decision-making}

To drive this research, we can look to the traditional, rational decision-making framework- the Shadow of Trial (SoT), which hypothesizes the defendant's plea decision will be based on the perceived outcome at trial, determined by the strength of the evidence (Mnookin \& Kornhauser, 1979). There is a wealth of research on defendant decisions that supports this framework; as the defendant's probability of conviction at trial increases, they are more willing to accept a guilty plea (Bordens, 1984; McAllister \& Bregman, 1986b). While, SoT was conceptualized to account for defendants' decisions, it can easily be used to predict the behavior of defense attorneys (and other legal actors; Bushway, Redlich, \& Norris, 2014). Defense attorneys use legal variables to inform plea decisions (e.g., evidentiary factors; Redlich, Bushway, \& Norris, 2016) - one such factor is the defendant's likelihood of conviction at trial based on the strength of evidence. 
PRE-PRINT Henderson, K. S. (forthcoming). Examining the Effect of Case and Trial Factors on Defense Attorneys' Plea Decision-making. Psychology, Crime \& Law. https://doi.org/10.1080/1068316X.2020.1805744

Research has found that as the defendant's probability of conviction at trial increases, defense attorneys become more willing to plea bargain (McAllister \& Bregman, 1986a). In two studies, the defendant's likelihood of conviction (based on the strength of the evidence) was listed as the most important factor informing attorney plea decisions (Edkins, 2011; Kramer, Wolbransky, \& Heilbrun, 2007). Defense attorneys are attuned to the strength of evidence; for example, defense attorneys were more likely to recommend the defendant accept a guilty plea when there was confession evidence, a positive eyewitness identification, and a DNA match than when such evidence was not present (Redlich et al., 2016). As SoT predicts, defense attorneys are looking to possible trial outcomes, based on the evidence, to inform their plea/trial strategies.

\section{Experiment One Overview}

This experiment tested the effect of jury verdict rules on defense attorneys' plea decisionmaking. Defense attorneys read a case summary of a defendant charged with robbery and assault, in which the jury verdict rule of the jurisdiction varied (majority rule vs. unanimous). Afterwards, participants made a plea decision, and rated their perceptions of the case, the defendant, and potential plea and trial outcomes. Our key hypotheses are outlined below.

\section{Mediation analyses}

a. Likelihood of conviction on plea decision. While we expected a main effect of jury verdict rule on plea decisions, we predicted this effect would be best explained as a mediating mechanism. That is, the effect of jury verdict rule on plea decisions would be mediated by likelihood of conviction. Jury verdict rule (unanimous v. majority rule) would influence defense attorneys' ratings of the defendants' likelihood of conviction at trial, which would influence their willingness to go to trial versus plead guilty (recommendations to their client). 
PRE-PRINT Henderson, K. S. (forthcoming). Examining the Effect of Case and Trial Factors on Defense Attorneys' Plea Decision-making. Psychology, Crime \& Law. https://doi.org/10.1080/1068316X.2020.1805744

\section{Main effect of jury verdict rule}

a. Willingness to plea bargain ratings. We expected this effect would extend to participants' willingness to plea ratings (both their own willingness and their perception of the other legal actor's willingness to plea bargaining). That is, defense attorneys would rate their own willingness to recommend accepting any plea bargain lower, and prosecutors' willingness to offer any plea bargain higher in unanimous conditions compared to majority rule conditions.

b. Probability of winning at trial. We also expected that defense attorneys would rate their likelihood of winning at trial higher in unanimous conditions compared to majority rule conditions.

\section{Experiment 1 Method}

\section{Participants}

Defense attorneys were eligible to participate if they were 18 years of age or older and practicing in the state of Oregon. In total, 82 defense attorneys participated. Years of experience ranged from one to 44 years $(M=18.35, S D=13.29)$. In this sample, 39 attorneys $(47.6 \%)$ described the jurisdiction they work in as "urban", 26 attorneys (31.7\%) "rural", and 15 attorneys $(18.3 \%)$ as "neither" (two attorneys did not respond). Defense attorneys responded that 87.92\% of their cases end in plea bargains each year $(\operatorname{Min}=50.00 \%, \operatorname{Max}=99.00 \%, S D=7.99)$. This is consistent with the national average (Cohen \& Reaves, 2006). Our sample was $61 \%$ male and $36.6 \%$ female (two attorneys "preferred not to answer" or did not respond). Overall, $89 \%$ of attorneys reported their race as White, 2.4\% as Hispanic, and 6.1\% as other races/ethnicities (two attorneys did not respond). This is consistent with the state of Oregon, which is currently $86.8 \%$ 
PRE-PRINT Henderson, K. S. (forthcoming). Examining the Effect of Case and Trial Factors on Defense Attorneys' Plea Decision-making. Psychology, Crime \& Law. https://doi.org/10.1080/1068316X.2020.1805744

Caucasian (Quick Facts Oregon, 2019). Similarly, 88.9\% of lawyers in the U.S. are Caucasian

(U.S. Department of Labor, 2012).

\section{Materials}

\section{Case Summary}

The case summary was written to be in accordance with state statutes and included typical case information that defense attorneys would be aware of in anticipation of evaluating potential case outcomes (available by request). Similar to Edkins (2011), our hypothetical case summary included information on the crime, the suspect, and the evidence. Defense attorneys were asked to imagine themselves the defense attorney in anticipation of taking this case to trial. Based on random assignment, half of participants were instructed that the jurisdiction on this matter uses a majority rule verdict decision and the other half a unanimous verdict decision. That is, in this experiment, we manipulated the jury verdict rule.

All the following information regarding the case remained constant. Participants read the case summary of a defendant charged with Robbery in the $1^{\text {st }}$ degree and Assault in the $2^{\text {nd }}$ degree, which if convicted carried a minimum punishment of 90 months (concurrent) or maximum of 160 months (consecutive) in state prison. The crime the defendant was charged with involved an accusation of robbing an adult male at knifepoint. The victim handed over their wallet and watch, after which, the robber slashed the victim's arm and pushed him to the ground. The victim described the robber as a, "White male in his twenties, wearing black sweat pants and a blue Yankee's cap." The suspect was not known to the victim. Near the crime scene, the police found the victim's wallet and a blue Yankee's cap similar to the one worn by the robber. The police apprehended the suspect later that day, however, none of the victim's property was found on the suspect. 
PRE-PRINT Henderson, K. S. (forthcoming). Examining the Effect of Case and Trial Factors on Defense Attorneys' Plea Decision-making. Psychology, Crime \& Law. https://doi.org/10.1080/1068316X.2020.1805744

The evidence included a positive identification of the suspect on the same day of the robbery. DNA testing of the Yankee's cap found near the crime scene came back inconclusive; DNA testing of the knife matched the victim only. Participants read that the defendant's criminal history involved Theft in the $1^{\text {st }}$ degree and possession of a controlled substance convictions. Defense attorneys were asked how they would choose to resolve the case (i.e., recommendation to their client), in addition to other questions assessing perception of case outcomes.

\section{Questionnaire and Dependent Variables}

The dependent measures in this experiment can be classified into two groups: specific to the case summary (to test the research question) and general to the topic of jury verdict rules.

Plea decision. Participants were asked: "Given the facts, how would you choose to resolve this case (advise your client)?" [plead this case (guilty plea) vs. take this case to trial]

Willingness to plea bargain. Participants rated their willingness to plea bargain on a 20point interval scale ranging from $0 \%$ to $100 \%$ (5-point intervals): What is the likelihood that you would recommend accepting any plea bargain to the defendant? Defense attorneys were also asked their perception of the prosecutor's willingness to plea bargaining. Participants rated these perceptions on a 20 -point interval scale ranging from $0 \%$ to $100 \%$ (5-point intervals): "What is the probability that the prosecutor would offer any plea bargain to the defendant?"

Defendant's likelihood of conviction. Participants rated the defendant's likelihood of conviction at trial on a 20 -point interval scale ranging from $0 \%$ to $100 \%$ (5-point intervals).

Probability of winning at trial. Participants rated their probability of winning the case if it went to trial on a 20 -point interval scale ranging from $0 \%$ to $100 \%$ (5-point intervals). For defense attorneys, winning is defined as acquittal. 
PRE-PRINT Henderson, K. S. (forthcoming). Examining the Effect of Case and Trial Factors on Defense Attorneys' Plea Decision-making. Psychology, Crime \& Law. https://doi.org/10.1080/1068316X.2020.1805744

Sentencing options. Participants were asked to indicate the average sentence the defendant would likely receive if he went to a jury trial and was convicted (participants wrote in the number of months). In addition, participants indicated the highest plea offer they would recommend accepting to the defendant in this scenario (participants wrote in the number of months). When attorneys provided a range (e.g., 80-90 months), responses were coded as the lower bound given.

Perception of jury verdict rule. The following questions assessed general attitudes of unanimous/majority rule juries. Statements used a 6-point Likert-type scale with 1 indicating 'strongly disagree' and 6 indicating 'strongly agree'. Items include: (a) It is easier to get a conviction with a unanimous verdict rule than a non-unanimous; (b) Convincing a unanimous jury will be more difficult than convincing a non-unanimous jury; (c) Non-unanimous jury rules undermine the requirement that guilt be proven beyond a reasonable doubt; (d) Non-unanimous verdict rules create a greater risk for wrongful conviction; (e) Non-unanimous verdict rules harm minorities in the criminal justice system; and (f) Hung juries are more likely to occur with a unanimous jury than majority rule jury.

Participants were also asked if changing the jury verdict rule from non-unanimous (majority rule) to unanimous in Oregon would affect their willingness to take cases to trial (Likert-type scale).

Qualitative questions. Participants were asked the following open-ended questions: (a) "If the jury verdict rule were unanimous, rather than majority, do you think that would influence defendants' plea decision-making? How so?"; and (b) "If the verdict decision rule were unanimous, rather than majority, would it affect how you handle cases? How so?" Qualitative 
PRE-PRINT Henderson, K. S. (forthcoming). Examining the Effect of Case and Trial Factors on Defense Attorneys' Plea Decision-making. Psychology, Crime \& Law. https://doi.org/10.1080/1068316X.2020.1805744

responses were coded by two independent, research assistants, blind to condition. Disagreement was resolved via a consensus meeting between coders.

Manipulation check question. To access sensitivity to our manipulation, participants were asked: "In the above-mentioned scenario (hypothetical case), what was the jury verdict rule?" [majority rule vs. unanimous]. Overall, defense attorneys were sensitive to this manipulation. Defense attorneys in unanimous conditions were more likely than those in majority rule conditions to accurately state the jury verdict rule was unanimous $(81.6 \%$ vs. $6.8 \%), \chi^{2}(1, N=82), 46.96, p<0.001$.

Demographic information. Participants indicated their gender and racial/ethnic background. Participants were asked how many years they have been working in their current role, roughly what percent of their cases end in plea bargains each year, and to describe the jurisdiction that they work in [urban, rural, neither]. When attorneys provided a range (e.g., seven-nine years), responses were coded as the lower bound given. There were no significant differences between manipulated conditions (i.e., randomization was successful).

\section{Procedure}

The University Institutional Review Board approved all materials and procedures prior to the collection of these data. Participants were recruited primarily through email requests (similar to Edkins, 2011; Redlich et al., 2016). Email solicitations were sent out through the state-wide lawyers association, which lists 784 members as "Attorneys at Large" (i.e., filtering out those listed as paralegals, victim outreach specialists, etc.). This round of email solicitation yielded a $10.5 \%$ response rate, similar to other work that has recruited defense attorneys through email solicitations (e.g., Edkins, 2011). The email invitations described the purpose of the experiment, that participation was voluntary and anonymous (no identifying information will be collected), 
PRE-PRINT Henderson, K. S. (forthcoming). Examining the Effect of Case and Trial Factors on Defense Attorneys' Plea Decision-making. Psychology, Crime \& Law. https://doi.org/10.1080/1068316X.2020.1805744

and provided the Qualtrics survey link. Once participants were directed to Qualtrics, they first viewed the informed consent. Then, all participants read a hypothetical case summary (varied based on condition), and answered a questionnaire, assessing their perceptions of the case, and demographical information.

\section{Experiment One Results}

Below we separate our results by categories of key dependent measures.

\section{Plea Decision}

Overall, $70.7 \%(N=58)$ of attorneys would advise their client to take this case to trial and $25.6 \%(N=21)$ would advise their client to plea bargain/accept a guilty plea $(N=$ three attorneys did not respond).

\section{Likelihood of Conviction on Plea Decisions}

We ran a simple mediation analysis using Process v3.3 macro in SPSS (Hayes, 2018). We expected that defense attorneys' likelihood of conviction at trial ratings $(\mathrm{M})$ would mediate the relationship between jury verdict rule $(\mathrm{X})$ and plea decision $(\mathrm{Y})$. See Figure 1. Jury verdict rule did not have a direct effect or indirect effect on defense attorneys' plea decisions; direct effect, $B=0.15, S . E=0.63, p=.809,95 \% \mathrm{CI}[-1.09,1.40]$, and indirect effect coefficient, $B=-$ 3.06, S.E $=0.53,95 \%$ CI $[-1.39,0.68]$. Rather, there was a significant effect of likelihood of conviction at trial on defense attorneys' plea decisions, $B=0.12, S . E=0.03, z=3.69, p<.001$, 95\% CI $[0.06,0.19]$. A post hoc analysis indicated that defense attorneys who rated the defendants' likelihood of conviction lower $(M=51.53)$ were more likely to want to take the case to trial than those who rated the defendants' likelihood of conviction higher $(M=71.76), d=-$ $1.46,95 \%$ CI [-2.00, -0.91$]$. Defense attorneys' ratings of the defendant's likelihood of 
PRE-PRINT Henderson, K. S. (forthcoming). Examining the Effect of Case and Trial Factors on Defense Attorneys' Plea Decision-making. Psychology, Crime \& Law. https://doi.org/10.1080/1068316X.2020.1805744

conviction at trial ranged from $19 \%$ to $95 \%(M=56.76, S D=16.40)$. See Figure 2 for a graph of the effect of likelihood of conviction on defense attorney's plea decisions.

Because likelihood of conviction was not an experimental manipulation, we conducted the same mediation model, but included appropriate covariates in the analysis $(\mathrm{C}=$ gender; $\mathrm{C}=$ years of experience, $\mathrm{C}=$ jurisdiction); the results did not change.

\section{Willingness to Plea Bargain}

We predicted a main effect of jury verdict rule of defense attorneys' willingness to plea bargain and perception of prosecutors' willingness to offer a plea. Because of the weak correlation between these variables, we ran separate models. See Table 1 for comprehensive correlations. In an independent samples t-test, we examined the effect of jury verdict rule (IV) on defense attorneys' willingness to plea bargain (DV). Defense attorneys in majority rule conditions were no more willing to plea bargain $(M=45.63, S D=29.90)$ than those in unanimous conditions $(M=44.06, S D=21.25), t(75)=-0.26, p=.797$. Defense attorneys' willingness to plea bargain (recommend any plea bargain to their client) ranged from $0 \%$ to $100 \%(M=44.94, S D=26.89)$. When asked the highest offer they would recommend accepting, responses ranged from 0 to 120 months $(M=54.13$ months, $S D=27.90)$.

The variable assessing defense attorneys' perceptions of prosecutors' willingness to offer a plea bargain was negatively skewed. We transformed the variable, as well as created a categorical variable of defense attorneys" "sureness" of an offer, neither of these models changed the interpretation of the results, so we present the untransformed analysis. In an independent samples t-test, we examined the effect of jury verdict rule (IV) on perceptions of the prosecutors' willingness to plea bargain (DV). Defense attorneys did not perceive prosecutors' willingness to plea bargain differently in majority rule $(M=89.39, S D=15.06)$ versus unanimous conditions 
PRE-PRINT Henderson, K. S. (forthcoming). Examining the Effect of Case and Trial Factors on Defense Attorneys' Plea Decision-making. Psychology, Crime \& Law. https://doi.org/10.1080/1068316X.2020.1805744

$(M=84.67, S D=16.75), t(78)=-1.33, p=.189$. Defense attorneys' estimates of the prosecutors' willingness to plea bargain ranged from $33 \%$ to $100 \%(M=87.26, S D=15.92)$. Interestingly, $64.5 \%$ of defense attorneys $(N=54)$, said there was a $90 \%$ chance or better that the prosecutor would offer a plea bargain.

\section{Perception of Trial Outcomes}

We expected a main effect of jury verdict rule on defense attorneys' ratings of their probability of winning at trial. We ran an independent samples t-test to examine the effect of jury verdict rule (IV) on defense attorneys' probability of winning at trial ratings (DV). Defense attorneys in unanimous conditions did not rate their likelihood of winning at trial higher $(M=$ $45.61, S D=16.64)$ than those in majority rule conditions $(M=47.02, S D=17.52), t(77)=-$ $0.37, p=.716$. Defense attorneys' estimates of their probability of winning at trial ranged from $10 \%$ to $82 \%(M=46.38, S D=17.03)$. While jury verdict rule did not have an effect on probability of winning ratings, defense attorneys' estimates of their likelihood of winning were associated with their plea decisions, Wald's $X^{2}=12.60, p<0.001, \exp (\mathrm{B})=.93,95 \% C I[0.89$, 0.97]. Defense attorneys who rated their likelihood of winning higher $(M=50.68)$ were more likely to want to go to trial than those who rated their likelihood of winning lower $(M=33.81), d$ $=1.10,95 \%$ CI $[0.56,1.63]$. See Figure 3 for a graph of the effect of defense attorneys' perceptions of their probability of winning on their plea decisions.

And lastly, when asked the average sentence the defendant would receive if he went to trial and was convicted, defense attorney responses ranged from 30 to 160 months $(M=97.24$ months, $S D=22.17)$. The majority of attorneys $(92.3 \%)$, responded that the defendant would 
PRE-PRINT Henderson, K. S. (forthcoming). Examining the Effect of Case and Trial Factors on Defense Attorneys' Plea Decision-making. Psychology, Crime \& Law. https://doi.org/10.1080/1068316X.2020.1805744

likely receive 90 to 160 months; this aligns with the sentencing guidelines (and information provided in our hypothetical case scenario). ${ }^{1}$

\section{Effect of Attorney Characteristics}

We ran the above analyses according to our hypotheses (the expected effect of jury verdict rule). We also ran these analyses as full models including demographic variables to examine for effects of attorney characteristics on decisions. The full models did not change the substantive finding of our key independent variable- jury verdict rule. Thus, this effect was not sensitive to model specification. See Table 2. In this experiment, as years of experience increased, defense attorneys' perception of the prosecutors' willingness to plea bargain decreased and their ratings of the average sentence the defendant would receive if convicted at trial increased (lengthier). Additionally, attorneys in rural jurisdictions rated the average sentence the defendant would receive if convicted at trial as longer than those in urban jurisdictions. These findings are exploratory, and future research should consider examining them more fully.

\section{Perception of Jury Verdict Rules (Generally)}

Participants responded to items assessing general attitudes of unanimous/majority rule juries, measured on 6-point Likert scales. Responses can be found in Table 3. When asked about Oregon's jury verdict rule specifically, $64.2 \%$ of participants somewhat to strongly agreed with the statement that changing Oregon's verdict rule from non-unanimous (majority) to unanimous would affect their willingness to take cases to trial (35.8\% somewhat to strongly disagreed with the statement; overall $M=3.69, S D=1.73$ ).

\footnotetext{
${ }^{1}$ We conducted these same analyses excluding those who failed the jury verdict manipulation check $(N=10)$. The results were consistent with those presented here.
} 
PRE-PRINT Henderson, K. S. (forthcoming). Examining the Effect of Case and Trial Factors on Defense Attorneys' Plea Decision-making. Psychology, Crime \& Law. https://doi.org/10.1080/1068316X.2020.1805744

Participants were also asked two open-ended questions assessing their perception of how the jury verdict rule affects defendants' decisions and their handling of cases. See Tables 4 and 5 for a summary of qualitative responses. The majority of defense attorneys (64.5\%) said that if the jury verdict rule were unanimous rather than majority-rule it would affect defendants' plea decision-making. Of those who responded that it would affect defendants' decisions, 22.2\% believed unanimity would lead to better plea offers. The remaining themes referenced trials; $28.6 \%$ believed that unanimity would lead to more trials, $17.4 \%$ referenced hung juries, $14.3 \%$ referenced the likelihood of conviction, and $17.4 \%$ referenced convincing juries (threshold for conviction). Conversely, $27.6 \%$ did not believe that it would affect defendants' decisions.

Similarly, the majority of defense attorneys $(60.8 \%)$ agreed that if the jury verdict rule were unanimous rather than majority rule it would affect how they handle cases. These responses were similar to those regarding defendant decision-making; $16.7 \%$ noted that it would lead to better plea offers/deals, $40.7 \%$ said it would increase their willingness to go to trial, $7.4 \%$ referenced hung juries, and $13 \%$ noted that the threshold for conviction would be higher (easier to convince juries). $5.5 \%$ said that unanimity would make the state less comfortable, and they might not believe they have as strong a chance of winning. Overall, 33.8\% did not believe it would affect how they handle cases; noting that they do not consider the jury's verdict rule, and how they handle cases is dictated by the facts of the case and whether it is "triable".

\section{Experiment One Discussion}

Overall, we did not find support for our hypothesis that jury verdict rule would influence defense attorneys' plea decisions (and other similarly related DVs). Rather, defense attorneys' estimates of the defendant's likelihood of conviction at trial predicted plea decisions. Defense attorneys who estimated that the defendant had a higher likelihood of conviction at trial were 
PRE-PRINT Henderson, K. S. (forthcoming). Examining the Effect of Case and Trial Factors on Defense Attorneys' Plea Decision-making. Psychology, Crime \& Law. https://doi.org/10.1080/1068316X.2020.1805744

more likely to recommend plea bargaining than those who estimated the defendant's likelihood of conviction lower. This is in line with predictions of SoT (Mnookin \& Kornhauser, 1979), and consistent with other research (McAllister \& Bregman, 1986a).

Defense attorneys' estimates of the defendant's probability of conviction at trial were inversely related to perceptions of their likelihood of winning at trial (Pearson's $r=-.716, p<$ .001). As defense attorneys' ratings of the defendant's likelihood of conviction increased, ratings of likelihood of winning at trial decreased. In graphing the relationship between these variables and plea decisions (see Figures 2 and 3), we can see decision thresholds for willingness to recommend plea bargaining (see Swets, Dawes, \& Monahan, 2000). In looking at defense attorneys' estimates of the defendant's likelihood of conviction, at the $40-59 \%$ threshold, there is a steep increase in willingness to recommend plea bargaining. For defense attorneys who estimated the defendant's likelihood of conviction below 39\%, willingness to plea flatlined. In looking at defense attorneys' estimates of their likelihood of winning at trial, at the 40-59\% threshold, there is an increase in willingness to go to trial. Importantly, this was not a strict test of cutpoints (Swets et al., 2000), nor did we manipulate probability of conviction. However, from these data, we can see threshold points where defense attorneys' decisions diverge between going to trial or plea bargaining. We encourage future work to examine this topic in a more systematic manner.

Defense attorneys were attuned to the effects of jury verdict rule, although this did not drive plea decisions. Defense attorneys believed that it is more difficult to convince a jury and secure a conviction with a unanimous jury than majority rule; this is consistent with research suggesting convictions are more likely with non-unanimous juries than unanimous (Buckhout et al., 1977). This was also evident in the $64.2 \%$ of defense attorneys who agreed that changing the 
PRE-PRINT Henderson, K. S. (forthcoming). Examining the Effect of Case and Trial Factors on Defense Attorneys' Plea Decision-making. Psychology, Crime \& Law. https://doi.org/10.1080/1068316X.2020.1805744

verdict rule from non-unanimous to unanimous would affect their willingness to take cases to trial. Similarly, consistent with past research (Kerr et al., 1976), defense attorneys believed that hung juries are more likely with unanimous juries than non-unanimous juries. And lastly, defense attorneys believed that non-unanimous verdict rules harm minorities in the system, undermine the requirement of guilt beyond a reasonable doubt, and can increase the risk of wrongful conviction; an important concern given the recent exoneration of a man convicted by a non-unanimous jury (Selsky, 2018). These themes were also noted in defense attorneys' qualitative statements; $60.8 \%$ of responses indicated that if the jury verdict rule were unanimous rather than majority rule, it would affect how defense attorneys handle cases (e.g., more desirable plea offers, increased willingness to go to trial). Similarly, $64.5 \%$ of qualitative responses indicated that if the jury verdict rule were unanimous rather than majority rule, it would affect defendant plea decision-making (e.g., more defendants would take their cases to trial).

\section{Experiment Two Overview}

In experiment one we did not see an effect of jury verdict rule on defense attorney plea decision-making; rather, we saw an effect of perceived probability of conviction at trial, which offers support for the SoT framework. However, without manipulating the strength of evidence or the defendant's likelihood of conviction at trial, we did not explicitly test SoT.

Our main hypothesis in experiment one was that jury verdict rule would influence defense attorney plea decisions, through estimates of the defendant's likelihood of conviction at trial. However, this might only be evident in cases where the evidence is strong, and therefore, defense attorneys are cognizant of the risks of conviction already. For example, when evidence is strong and the jury verdict rule is majority rule, defense attorneys could be less willing to go to trial than if the jury required unanimity. It is possible that when the evidence is weak, defense 
PRE-PRINT Henderson, K. S. (forthcoming). Examining the Effect of Case and Trial Factors on Defense Attorneys' Plea Decision-making. Psychology, Crime \& Law. https://doi.org/10.1080/1068316X.2020.1805744

attorneys would be riskier and take the case to trial regardless of the jury verdict rule. This could help to explain the overall high percentage of defense attorneys willing to go to trial in experiment one (plea rate of $25.6 \%$, much lower than the national average $-90-95 \%$ ). Thus, in experiment two we tested the interaction effect of strength of evidence and jury verdict rule on defense attorney decisions.

Defense attorneys read a case summary of a defendant charged with unauthorized use of a vehicle and driving under the influence, in which the jury verdict rule and strength of the evidence varied. Similar to experiment one, after reading the case summary, defense attorneys rated their perceptions of the case, the defendant, and potential plea and trial outcomes. Our key hypotheses are outlined below.

\section{Main effect of strength of evidence}

a. Highest plea offer. We expected the deal defense attorneys felt they could get (highest plea offer they would recommend accepting) would be worse (more severe) in strong evidence conditions compared to weak.

b. Belief in defendant's actual guilt. We expected that defense attorneys would rate the accused's actual guilt higher in strong evidence conditions compared to weak.

\section{Interaction effect of strength of evidence and jury verdict rule}

a. Plea decision. We expected an interaction between jury verdict rule and strength of evidence on plea decisions. Such that, defense attorneys would be more willing to recommend pleading guilty in strong evidence conditions facing a majority rule jury compared to all other conditions.

b. Willingness to plea bargain ratings. We expected defense attorneys would rate their own willingness to recommend accepting any plea bargain higher in 
PRE-PRINT Henderson, K. S. (forthcoming). Examining the Effect of Case and Trial Factors on Defense Attorneys' Plea Decision-making. Psychology, Crime \& Law. https://doi.org/10.1080/1068316X.2020.1805744

majority rule conditions with strong evidence compared to all other conditions.

Because past research suggests prosecutors are more willing to plea bargain with weak evidence (see Bibas, 2004), we expected defense attorneys would rate prosecutors' willingness to bargain higher in weak evidence conditions compared to strong. This effect could be amplified in unanimous jury verdict conditions.

c. Probability of conviction and likelihood of winning at trial. We expected that defense attorneys would rate the defendant's probability of conviction lower and their likelihood of winning at trial higher in unanimous conditions with weak evidence compared to majority rule and strong evidence conditions.

\section{Experiment Two Method}

\section{Design}

Experiment two replicated and extended findings from experiment one by also manipulating the strength of the evidence in the case. The experiment used a 2 (jury verdict rule: majority rule vs. unanimous) X 2 (strength of the evidence: weak vs. strong) between subjects factorial design. Participants were randomly assigned to one of the four conditions.

\section{Participants}

Similar to experiment one, defense attorneys were eligible to participate if they were 18 years of age or older and practicing in the state of Oregon. In total, 81 defense attorneys participated. Years of practice ranged from less than one year to 47 years $(M=16.73, S D=$ 12.73). In our sample, 41 attorneys $(50.6 \%)$ described the jurisdiction they work in as "urban", 22 attorneys (27.2\%) "rural”, and 18 attorneys (22.2\%) as "neither". Defense attorneys responded that $84.39 \%$ of their cases end in plea bargains each year $(\operatorname{Min}=50.00 \%$, Max $=$ 98.00\%, $S D=11.55$ ). Our sample was $70.4 \%$ male and $23.5 \%$ female (five attorneys "preferred 
PRE-PRINT Henderson, K. S. (forthcoming). Examining the Effect of Case and Trial Factors on Defense Attorneys' Plea Decision-making. Psychology, Crime \& Law. https://doi.org/10.1080/1068316X.2020.1805744

not to answer" or did not respond). And, $87.7 \%$ of attorneys reported their race as White, $1.2 \%$ as Black, non-Hispanic, $4.9 \%$ as Hispanic, and 3.7\% as other races/ethnicities (two attorneys did not respond).

\section{Materials}

\section{Case Summary}

Similar to experiment one, defense attorneys were asked to imagine themselves the defense attorney in anticipation of taking this case to trial. Half of participants were instructed that the jurisdiction on this matter uses a majority rule verdict decision and the other half a unanimous verdict decision. The case summary is available by request.

To maximize external validity and avoid any confusion should participants have participated in experiment one, the case summary involved a different crime type and charges. The charges remained constant across conditions. Participants read the case summary of a defendant charged with Unauthorized Use of a Vehicle (UUV) and Driving Under the Influence (DUI), which if convicted carried a minimum punishment of 15 months or maximum of 18 months (roughly). In this case, a male suspect was pulled over for erratic driving in the early hours of the morning on a quiet, side road. The officer reported a broken driver's side window, noticed a punched-out ignition (common in stolen vehicles), a meth pipe (in plain sight), and a witness sitting in the passenger seat.

The strength of evidence in the case varied based on random assignment (weak vs. strong). As the presence of confession evidence and an eyewitness identification influences plea decisions (Redlich, Bushway, \& Norris, 2016), we varied the quality of the witness's statement (passenger seat occupant) and the content of the defendant's statement/admission. In all conditions, the police officer asked the suspect, "Is this your vehicle?". In weak evidence 
PRE-PRINT Henderson, K. S. (forthcoming). Examining the Effect of Case and Trial Factors on Defense Attorneys' Plea Decision-making. Psychology, Crime \& Law. https://doi.org/10.1080/1068316X.2020.1805744

conditions, the suspect replied, "A friend loaned it to me. Big deal”. In strong evidence conditions, the suspect replied, "Man, I was just walking down the street, saw the car...looked like it didn't belong to anybody...bought some gas and took it, okay." The police officer then asked if the suspect noticed the punched-out ignition, to which the suspect replied, "Yeah, what's the big deal?" After making this statement, the suspect refused to answer other questions.

The police officer then questioned the witness. In weak evidence conditions, the witness replied, "I have nothing to say. Can I go?" The officer let her leave the scene, and her current whereabouts and if she will testify are unknown. In strong evidence conditions, the witness replied, "Listen, I saw him break the window and punch the ignition." The witness is on record. Participants read that the defendant's criminal history involves one Robbery in the $1^{\text {st }}$ and possession of controlled substance convictions. Therefore, in this experiment, defense attorneys read a case summary where the defendant was charged in a jurisdiction that used a unanimous (or majority rule) jury verdict rule and the evidence against the defendant was strong (or weak).

\section{Questionnaire and Dependent Variables}

Plea decision, willingness to plea bargain, defendant's likelihood of conviction, and probability of winning at trial. Participants answered the same plea decision (plead guilty vs. trial), willingness to plea bargain (themselves and perception of the prosecutor), defendant's likelihood of conviction, and probability of winning at trial questions used in experiment one.

Sentencing options. Participants were also asked the same two questions about sentencing options used in experiment one; however, in experiment two, response options were added so as not to conflate "zero" months with "no jail time" or "never accept" a guilty plea. That is, participants were asked to indicate the average sentence the defendant would likely receive if he went to a jury trial and was convicted; participants either wrote in the number of 
PRE-PRINT Henderson, K. S. (forthcoming). Examining the Effect of Case and Trial Factors on Defense Attorneys' Plea Decision-making. Psychology, Crime \& Law. https://doi.org/10.1080/1068316X.2020.1805744

months or indicated that the defendant would receive no jail time. Participants were also asked to indicate the highest plea offer they would recommend accepting; participants either wrote in the number of months, indicated that they would only accept a plea that included "no jail time", or that they would recommend "never accepting a plea". When attorneys provided a range, responses were coded as the lower bound given. When defense attorneys listed a range of days under one month (or said, "less than one month"), responses were coded as zero months.

Belief in the defendant's actual guilt. Participants rated their certainty about the defendant's actual guilt on a 5-point Likert scale; response options were: 1- Absolutely not guilty, 2- Probably not guilty, 3- Unsure, 4- Probably guilty, and 5- Absolutely guilty.

Case strategy. Participants were asked to indicate their approach to plea-bargaining in this case; response options were: 1- Never accept a plea, 2 - Accept a plea ONLY if it involves no jail time, 3- I'm indifferent about the terms of the plea, 4- Accept a plea if the terms re: incarceration time are decent, 5- Accept a plea if the terms re: incarceration time are good, and 6This is my client's choice.

Manipulation check questions. Participants were asked the same question regarding the jury verdict rule (correct response varied by condition). Similar to experiment one, participants were sensitive to this manipulation. Defense attorneys in unanimous conditions were more likely than those in majority rule conditions to accurately state the jury verdict rule was unanimous (93.9\% vs. $17.4 \%), \chi^{2}(1, N=79), 45.05, p<0.001$. To access sensitivity to our strength of evidence manipulation, participants were asked to rate the strength of evidence in the case; this was measured on a 6-point Likert scale ranging from 1- Extremely weak to 6- Extremely strong. Participants in strong evidence conditions rated the evidence in the case stronger $(M=4.88)$ than those in weak evidence conditions $(M=3.87), t(78)=-4.35, p<.001$. 
PRE-PRINT Henderson, K. S. (forthcoming). Examining the Effect of Case and Trial Factors on Defense Attorneys' Plea Decision-making. Psychology, Crime \& Law. https://doi.org/10.1080/1068316X.2020.1805744

Demographic information. Participants answered the same questions regarding their gender, racial/ethnic background, jurisdiction type, years of experience, and what percentage of their cases result in plea bargains each year from experiment one. For years of experience, when a range was provided, responses were coded with the lower bound given ("less than one year" coded as zero). There were no significant differences between manipulated conditions (i.e., randomization was successful).

\section{Procedure}

The procedures for experiment two mirrored that of experiment one.

\section{Experiment Two Results}

Below we separate our results by categories of key dependent measures.

\section{Plea Decision}

Overall, $27.2 \%(N=22)$ of attorneys would advise their client to take this case to trial and $71.6 \%(N=58)$ would advise their client to plea bargain/accept a guilty plea $(N=$ one attorney did not respond). In a logistic regression model, we first examined the main effects of jury verdict rule and strength of evidence on defense attorneys' plea decisions. The overall model was significant, $\chi^{2}(2)=13.42, p=.001$. We found a significant main effect of strength of evidence on plea decisions, $B=1.93, S . E=0.68$, Wald's $\chi^{2}=8.04, p=.005, \exp (B)=6.89,95 \%$ $C I[1.82,26.12]$. Defense attorneys were more likely to recommend plea bargaining $(M=91 \%)$ in strong evidence conditions compared to weak evidence conditions $(M=59 \%), d=0.75,95 \%$ $C I[0.29,1.21]$. The main effect of jury verdict rule was not significant (unanimous, $M=82 \%$ versus majority rule, $M=64 \%), B=-.80, S . E=0.58$, Wald's $\chi^{2}=1.89, p=.169, \exp (B)=0.45$, $95 \% C I[0.15,1.40]$. We then ran the full model including the interaction effect of jury verdict 
PRE-PRINT Henderson, K. S. (forthcoming). Examining the Effect of Case and Trial Factors on Defense Attorneys' Plea Decision-making. Psychology, Crime \& Law. https://doi.org/10.1080/1068316X.2020.1805744

rule and strength of evidence; the interaction effect was not significant, $B=0.05, S . E=1.43$, Wald's $\chi^{2}=0.00, p=.973, \exp (B)=1.05,95 \% C I[0.06,17.38]$.

\section{Willingness to Plea Bargain}

We predicted an interaction effect between jury verdict rule and strength of evidence on defense attorneys' willingness to plea bargain. We ran an ANOVA examining the effect of jury verdict rule and strength of evidence (IVs) on defense attorneys' willingness to plea bargain. No effects were significant; effect of jury verdict rule, $F(1,73)=0.71, p=.403, \eta^{2}=.01$; effect of strength of evidence, $F(1,73)=0.21, p=.650, \eta^{2}=.00$; and the interaction effect, $F(1,73)=$ $0.25, p=.620, \eta^{2}=.00$. Defense attorneys' willingness to plea bargain (recommend any plea bargain to their client) ranged from $0 \%$ to $100 \%(M=50.21 \%, S D=28.52)$.

We expected strength of the evidence would influence the deal defense attorneys would be willing to recommend accepting. We separated the variable into those who "would never recommend accepting a plea", those who "would only recommend accepting a plea if it included NO jail time", and those who wrote in the plea deal they would be willing to recommend accepting (in months). Zero attorneys responded that they would never recommend accepting a plea in this case and $22.2 \%(N=18)$ said that they would only recommend accepting a deal of no jail time. $70.4 \%$ responded with some incarceration time, ranging from 1 to 24 months $(M=$ $11.63, S D=5.60)$. We transformed the responses of those who would recommend accepting a guilty plea only if it included NO jail time into zero months (creating a continuous variable ranging from 0-24 months). We then ran an independent samples t-test with strength of evidence (IV) on the highest plea offer defense attorneys would recommend accepting (DV). Defense attorneys in strong evidence conditions were more willing to recommend accepting a guilty plea 
PRE-PRINT Henderson, K. S. (forthcoming). Examining the Effect of Case and Trial Factors on Defense Attorneys' Plea Decision-making. Psychology, Crime \& Law. https://doi.org/10.1080/1068316X.2020.1805744

with more jail time $(M=11.63$ months, $S D=5.85)$ than those in weak evidence conditions $(M=$ 6.86 months, $S D=7.10), t(72)=-3.04, p=.003$.

On a separate question, we asked defense attorneys their "approach to plea bargaining in this case". Overall, $53.1 \%(N=43)$ responded that it's their client's choice, $24.7 \%(N=20)$ stated they would accept a deal if the terms were decent, 14.8\% $(N=12)$ stated that they would accept a deal if the terms were good, and 6.2\% $(N=5)$ said they would accept a plea ONLY if it included no jail time. No attorneys responded that they were indifferent about the terms of the plea offer or that they would never accept a plea. In this sample, about half of the defense attorneys approached the topic of plea bargaining attuned to the incarceration terms of the deal $(45.7 \%)$ and the other half noted that overall, the decision to plead is the client's choice.

We predicted an interaction effect between jury verdict rule and strength of evidence of defense attorneys' ratings of the prosecutors' willingness to plea bargain. Similar to experiment one, defense attorneys' perceptions of prosecutors' willingness to offer a plea bargain was negatively skewed. We transformed the data, which did not help with normality, thus we present the untransformed data. We ran an ANOVA examining the effect of jury verdict rule and strength of evidence (IVs) on defense attorneys' assessment of the prosecutors' willingness to plea bargain. No effects were significant; effect of jury verdict rule, $F(1,74)=2.65, p=.108, \eta^{2}$ $=.04$; effect of strength of evidence, $F(1,74)=0.39, p=.536, \eta^{2}=.01$; and the interaction effect, $F(1,74)=1.68, p=.200, \eta^{2}=.02$. Similar to experiment one, the vast majority of defense attorneys $(74 \%)$ believed there was a $90 \%$ chance or greater that the prosecutor would offer a plea bargain.

\section{Perception of Trial Outcomes}


PRE-PRINT Henderson, K. S. (forthcoming). Examining the Effect of Case and Trial Factors on Defense Attorneys' Plea Decision-making. Psychology, Crime \& Law. https://doi.org/10.1080/1068316X.2020.1805744

We expected an interaction effect between jury verdict rule and strength of evidence on defense attorneys' ratings of the defendant's likelihood of conviction and their probability of winning at trial. Because of the strong correlation between likelihood of conviction and probability of winning at trial (see Table 1), we ran a MANOVA with these variables as our DVs and jury verdict rule and strength of evidence as the IVs. As a note, transformation of the data did not help with normality, analyses were conducted on the untransformed data. At the multivariate level, there was a significant effect of strength of evidence, $\lambda=.82, F(2,72)=7.71$, $p=.001, \eta^{2}=.18$. The main effect of strength of evidence was significant for both likelihood of conviction, $F(1,73)=8.67, p=.004, \eta^{2}=.11$, and probability of winning estimates, $F(1,73)=$ $15.26, p<.001, \eta^{2}=.17$. Defense attorneys rated the defendant's likelihood of conviction higher in strong evidence conditions $(M=85.51)$ compared to weak evidence conditions $(M=71.40), d$ $=0.70,95 \% C I[0.23,1.17]$. Defense attorneys rated their probability of winning at trial higher in weak evidence conditions $(M=35.42 \%)$ compared to strong evidence conditions $(M=18.61), d$ $=0.93,95 \% C I[0.45,1.41]$. The multivariate effects of jury verdict rule and the interaction were not significant; $\lambda=.98, F(2,72)=0.75, p=.475, \eta^{2}=.02$ and $\lambda=.99, F(2,72)=0.51, p=.603$, $\eta^{2}=.01$, respectively

Similar to experiment one, defense attorneys' estimates of the defendant's likelihood of conviction and their probability of winning at trial were associated with their plea decisions, Wald's $X^{2}=19.37, p<0.001, \exp (B)=.1 .10,95 \% C I[1.06,1.15]$ and Wald's $X^{2}=17.39, p<$ $0.001, \exp (B)=0.86,95 \% C I[0.80,0.92]$. Defense attorneys who rated the defendant's likelihood of conviction higher $(M=85.59)$ were more likely to recommend plea bargaining than those who rated the defendant's likelihood of conviction lower $(M=54.18), d=1.97,95 \% C I$ $[1.38,2.55]$. Similarly, defense attorneys who rated their probability of winning lower were more 
PRE-PRINT Henderson, K. S. (forthcoming). Examining the Effect of Case and Trial Factors on Defense Attorneys' Plea Decision-making. Psychology, Crime \& Law. https://doi.org/10.1080/1068316X.2020.1805744

likely to want to plea bargain $(M=19.42)$ than those who rated their probability of winning higher $(M=51.86), d=-2.40,95 \% C I[-3.03,-1.76]$.

We expected that strength of evidence would affect defense attorneys' ratings of the accused's actual guilt. We examined this in an independent samples t-test; the effect of strength of evidence on ratings of the accused's actual guilt was not significant, $t(78)=-1.36, p=.179$. Responses ranged on a scale from 1 (absolutely not guilty) - 5 (absolutely guilty), $M=3.75, S D$ $=0.76$. In this sample, one defense attorney $(1.2 \%)$ responded that the accused was "absolutely not guilty", 3.7\% $(N=3)$ responded "probably not guilty", 24.7\% $(N=20)$ responded "unsure", $58 \%(N=47)$ responded "probably guilty", and $11.1 \%(N=9)$ responded that the accused was “absolutely guilty".

When asked the average sentence the defendant would receive if he went to a jury trial and was convicted, eight defense attorneys (9.9\%) stated that the defendant would receive no jail time, while $85.2 \%(N=69)$ said the defendant was facing jail time. This ranged from $1-24$ months $(M=14.33$ months, $S D=5.11)$. This average is longer than the highest plea offer defense attorneys would recommend accepting (regardless of evidence), demonstrating that defense attorneys are looking for a plea discount when recommending accepting the offer.

Lastly, because we had data on perceived probability of conviction at trial and average sentence if convicted, we calculated the expected value of going to trial (likelihood of conviction rating $\mathrm{X}$ expected sentence if convicted). We ran an ANOVA examining the effect of jury verdict rule and strength of evidence (IVs) on defense attorneys' expected value of going to trial. There was a significant main effect of strength of evidence, $F(1,71)=7.03, p=.010, \eta^{2}=.09$. Defense attorneys in strong evidence conditions had a higher expected value of going to trial ( $M$ $=12.40, S D=5.37)$ than those in weak evidence conditions $(M=8.88, S D=5.77), d=0.63$, 
PRE-PRINT Henderson, K. S. (forthcoming). Examining the Effect of Case and Trial Factors on Defense Attorneys' Plea Decision-making. Psychology, Crime \& Law. https://doi.org/10.1080/1068316X.2020.1805744

$95 \%$ CI $[0.15,1.10]$. The effect of jury verdict rule and the interaction were not significant, $F(1$, $71)=1.39, p=.242, \eta^{2}=.02$ and $F(1,71)=0.68, p=.411, \eta^{2}=.01 .^{2}$

\section{Effect of Attorney Characteristics}

We also ran analyses as full models including demographic variables to examine for effects of attorney characteristics on decisions. The full models did not change the substantive finding of our key independent variables. See Table 6. As years of experience increased, defense attorneys rated their likelihood of winning at trial lower and defendant's likelihood of conviction at trial higher. This, coupled with results from experiment one, suggest years of experience is an important characteristic to capture in examining attorney decision-making.

\section{Experiment Two Discussion}

In this experiment, we did not find support for the expected interaction between jury verdict rule and strength of evidence on plea decisions. Rather, strength of evidence had a clear effect on plea decisions; defense attorneys in strong evidence conditions were more likely to recommend their client accept a guilty plea than those in weak evidence conditions. We also did not see the expected interaction effect on defense attorneys' willingness to plea bargain or their perceptions of the prosecutors' willingness to offer a bargain.

Strength of evidence affected many dependent measures, lending stronger support for more traditional models of decision-making, such as SoT. Strength of evidence influenced defense attorneys' ultimate plea decision, the highest plea offer they would recommend

\footnotetext{
${ }^{2}$ We conducted the planned analyses for this experiment a second time excluding those who failed the jury verdict manipulation check question $(N=10)$ Additionally, two participants did not answer this question. The results from this data set were consistent with the results presented here with one exception. In examining the effect of strength of evidence on defense attorneys' perceptions of the defendant's actual guilt, the not significant effect (reported in the text) became significant $(t(66)=-2.49, p=.015)$. Defense attorneys in strong evidence conditions rated the defendant's actual guilt higher $(M=4.00, S D=0.48)$ than those in weak evidence conditions $(M=3.63, S D=0.73)$.
} 
PRE-PRINT Henderson, K. S. (forthcoming). Examining the Effect of Case and Trial Factors on Defense Attorneys' Plea Decision-making. Psychology, Crime \& Law. https://doi.org/10.1080/1068316X.2020.1805744

accepting, their ratings of the defendant's likelihood of conviction, estimates of their probability of winning at trial, and the expected value of going to trial. Similar to past research (Edkins, 2011), defense attorneys in strong evidence conditions recommended accepting a guilty plea that included more jail time than those in weak evidence conditions (average difference $=4.77$ months). Also in line with past research (Edkins, 2011), and the SoT framework, defense attorneys in strong evidence conditions rated the defendant's likelihood of conviction higher $(M$ $=85.51)$ and their probability of winning lower $(M=18.61)$ than those in weak evidence conditions (conviction, $M=71.40$; winning, $M=35.42 \%$ ). Similar to experiment one, likelihood of conviction and probability of winning estimates were both associated with plea decisions. In this experiment, we also found that defense attorneys in strong evidence conditions had a higher expected value of going to trial than those in weak evidence conditions.

We did not see the expected effect of strength of evidence on defense attorneys' ratings of the defendant's actual guilt. This is likely due to a lack of variation, $69.1 \%$ of defense attorneys believed the defendant to be "probably" or "absolutely" guilty. As this variable is correlated with defense attorneys' ultimate plea decision (see Table 1), we suggest including it in future work examining defense attorneys' plea decision-making.

And lastly, when asked their general approach to plea bargaining in this case, half of defense attorneys reported that the choice was their clients, while the other half reported a consideration for the amount of jail time offered in the plea (no jail time, decent, or good terms). Given this finding, and that client preference has been shown to be an important factor weighing into defense attorney plea decisions (Kramer et al., 2007), we suggest future research explore this component of decision-making further.

\section{General Discussion}


PRE-PRINT Henderson, K. S. (forthcoming). Examining the Effect of Case and Trial Factors on Defense Attorneys' Plea Decision-making. Psychology, Crime \& Law. https://doi.org/10.1080/1068316X.2020.1805744

Plea bargaining is believed to occur in the shadow of trial, and research supports that legal variables drive defense attorney decisions (McAllister \& Bregman, 1986a; Pezdek \& O'Brien, 2014). As defense attorneys are attuned to legal variables in their estimation of the "triability" of cases (Hollander-Blumoff, 2008), we expected that moving the threshold for conviction from non-unanimity to unanimity would influence defense attorneys' perception of trial outcomes and willingness to plea bargain (experiment one). We further expected that the effect of jury verdict rule would be most salient depending on the strength of evidence in the case (experiment two). Overall, we did not find support for our hypotheses that jury verdict influences defense attorney plea decision-making. And rather, found stronger support for variables captured under more traditional models of decision-making: probability of conviction and strength of evidence.

\section{Role of Strength of Evidence and Probability of Conviction}

In both experiments one and two, likelihood of conviction estimates were associated with defense attorneys' plea decisions. Defense attorneys who estimated a higher likelihood that the defendant would be convicted at trial were more likely to recommend plea bargaining. In experiment two, defense attorneys who recommended the defendant take the case to trial averaged a likelihood of conviction rate of $54.18 \%$, just above chance ratings. This percentage is in line with the decision threshold estimated in experiment one.

In experiment two we manipulated the strength of the evidence (a key variable of SoT). In line with past research (Redlich et al., 2016), when the evidence was strong, defense attorneys were more likely to recommend plea bargaining compared to when the evidence was weak. Strength of evidence also influenced defense attorneys' estimates of the defendant's likelihood of conviction and their probability of winning at trial. In strong evidence conditions, defense 
PRE-PRINT Henderson, K. S. (forthcoming). Examining the Effect of Case and Trial Factors on Defense Attorneys' Plea Decision-making. Psychology, Crime \& Law. https://doi.org/10.1080/1068316X.2020.1805744

attorneys rated the defendant's likelihood of conviction higher and their chances of winning at trial lower than weak evidence conditions. As one might expect, perceptions of the defendant's likelihood of conviction were inversely correlated with defense attorneys' estimates of their probability of winning at trial (see Table 1). Defense attorneys who estimated a higher probability of winning at trial (experiment one $=50.68 \%$ and experiment two $=51.86 \%$ ) were more likely to want to take the case to trial than those who estimated a lower chance of winning (experiment one $=33.81 \%$ and experiment two $=19.42 \%)$

And lastly, strength of evidence influenced the highest plea offer that defense attorneys would be willing to recommend accepting and the expected value of going to trial. Similar to Edkins (2011), we found that when the evidence was strong, defense attorneys were more willing to recommend accepting an offer that included more jail time than in weak evidence conditions (difference of almost five months). Strong evidence contributed to a higher expected value of going to trial estimate than weak evidence (roughly 12.5 months compared to nine months). For defense attorneys in strong evidence conditions, a plea offer of anything less than 12.5 months would be a good bargain, and anything less than nine months in weak evidence conditions a good bargain. Comparing this to the highest plea offer defense attorneys would recommend accepting, $M=11.63$ months in strong evidence conditions and $M=6.86$ months in weak evidence conditions, demonstrates that defense attorneys are attuned to the plea discount in considering the value of the offer and expected value of going to trial.

\section{Future Directions and Limitations}

In this study, years of experience affected defense attorneys' perception of the prosecutor's willingness to bargain, ratings of the defendant's likelihood of conviction, estimates of their probability of winning at trial, and the average sentence they believed the defendant 
PRE-PRINT Henderson, K. S. (forthcoming). Examining the Effect of Case and Trial Factors on Defense Attorneys' Plea Decision-making. Psychology, Crime \& Law. https://doi.org/10.1080/1068316X.2020.1805744

would receive if convicted at trial. Past research has also identified the effect of years of experience on case evaluation and outcome estimation; Edkins found that for every additional year the defense attorney practiced, the odds of them recommending accepting a plea including jail time increased (2011). Years of experience is a variable that future research should explore to better understand how this factor influences defense attorney decision-making.

In general, we saw a wide range of variation in willingness to plea (and offers defense attorneys were willing to accept), and estimates of trial and post-conviction measures. For example, defense attorneys' estimates of the highest plea offer they would recommend accepting ranged from 0 - 120 months (experiment one) and 0 - 24 months (experiment two). This suggests defense attorneys have different approaches to the practice of plea bargaining and of what constitutes a "good plea offer" in a given case. Similarly, defense attorneys' estimates of their probability of winning at trial ranged from $10-82 \%$ (experiment one) and $1-72 \%$ (experiment two). Defense attorneys relay their predictions to their clients, and this information influences defendant plea decision-making. These variations in defense attorney decision-making highlight the importance of better understanding how defense attorneys make case estimations and predictions.

While this study advances our understanding of defense attorney decision-making, it does come with limitations. Namely, the overall sample size. As noted by others (Pezdek \& O’Brien, 2014), it is difficult to get practicing attorneys to participate in research. Because of this, we limited the number of variables of interest (in models) to isolate those most relevant to our research questions. Another limitation is that we did not ask participants in experiment two if they participated in experiment one (nor did we prevent participation if they had). Experiment two used a different case summary with a different crime, data collection for experiment two 
PRE-PRINT Henderson, K. S. (forthcoming). Examining the Effect of Case and Trial Factors on Defense Attorneys' Plea Decision-making. Psychology, Crime \& Law. https://doi.org/10.1080/1068316X.2020.1805744

took place roughly 11 months after experiment one, and our response rate was roughly $10 \%$ of the entire membership. Because of this, we think it is likely that we have a strong portion of "new participants" in experiment two, and if not, because the materials are different, do not believe this undermines the data. However, future work should attempt to draw a larger sample of attorneys, and account for any repeat participation if the study involves multiple experiments.

\section{Conclusions}

This research suggests defense attorneys are cognizant of the dangers of non-unanimous jury decisions; specifically, defense attorneys believed non-unanimous juries lower the threshold for conviction. However, jury verdict rule did not affect plea decisions. In this study, we found stronger support for variables that fall under traditional models of rational decision-making (i.e., strength of evidence and defendant's likelihood of conviction), such as SoT. Strength of evidence affected defense attorneys' plea decisions, the plea offer they would be willing to accept, ratings of the defendant's likelihood of conviction, estimates of their probability of winning at trial, and the expected value of trial. However, we also found wide variation in case evaluation and estimation that would suggest defense attorneys are not always coming to the same conclusions in a given case (contradictory to rational models). This suggests research should continue to focus on understanding factors that affect actual decision-making (such as age and factual innocence, Helm, Reyna, Franz, \& Novick, 2018; years of experience, this study and Edkins, 2011), which violate rational decision-making as traditionally conceived. 
PRE-PRINT Henderson, K. S. (forthcoming). Examining the Effect of Case and Trial Factors on Defense Attorneys' Plea Decision-making. Psychology, Crime \& Law. https://doi.org/10.1080/1068316X.2020.1805744

\section{References}

Apodaca v. Oregon, 406 U.S. 404. (1972).

Bibas, S. (2004). Plea bargaining outside the shadow of a trial. Harvard Law Review, 117, 24632547. http://dx.doi.org/10.2307/4093404

Bordens, K. (1984). The effects of likelihood of conviction, threatened punishment, and assumed role on mock plea bargaining decisions. Basic and Applied Social Psychology, 5(1), 5974.

Bornstein, B.H. \& Greene, E. (2017). The jury under fire: Myth, controversy, and reform. New York, NY: Oxford Press.

Buckhout, R., Weg, S., Reilly, V., \& Frohboese, R. (1977). Jury verdicts: Comparison of 6- vs. 12-person juries and unanimous vs. majority decision rule in a murder trial. Bulletin of the Psychonomic Society, 10(3), 175-178.

doi:http://dx.doi.org.proxy.lib.pdx.edu/10.3758/BF03329315

Bushway, S.D., Redlich, A.D., \& Norris, R.J. (2014). An explicit test of plea bargaining in the "Shadow of the Trial". Criminology, 54(4), 723-754. doi: 10.1111/1745-9125.12054

Cohen, T. H., \& Reaves, B. A. (2006). Felony defendants in large urban counties, 2002. Washington, DC: U.S. Department of Justice, Office of Justice Programs, Bureau of Justice Statistics. Retrieved from http://www.bjs.gov/index.cfm?ty=pbdetail\&iid=896

Davis, J. H., Kerr, N. L., Atkin, R. S., Holt, R., \& Meek, D. (1975). The decision processes of 6and 12-person mock juries assigned unanimous and two-thirds majority rules. Journal of Personality and Social Psychology, 32(1), 1-14.

doi:http://dx.doi.org.proxy.lib.pdx.edu/10.1037/h0076849 
PRE-PRINT Henderson, K. S. (forthcoming). Examining the Effect of Case and Trial Factors on Defense Attorneys' Plea Decision-making. Psychology, Crime \& Law. https://doi.org/10.1080/1068316X.2020.1805744

Death Penalty Information Center (2018, January 17). Life Verdict or Hung Jury? How States Treat Non-Unanimous Jury Votes in Capital-Sentencing Proceedings. https://deathpenaltyinfo.org/stories/life-verdict-or-hung-jury-how-states-treat-non$\underline{\text { unanimous-jury-votes-in-capital-sentencing-proceedings }}$

Diamond, S. S., Rose, M. R., \& Murphy, B. (2006). Revisiting the unanimity requirement: The behavior of the non-unanimous civil jury. Northwestern University Law Review, 100(1), 201-230. Retrieved from https://pdfs.semanticscholar.org/f272/9ede868a8bfc5ad5aa1ca2d5e9ee0d54b1ae.pdf

Durose, M.R. \& Langan, P.A. (2007). Felony sentences in state courts, 2004. Bureau of Justice Statistics Bulletin. Retrieved from https://www.bjs.gov/content/pub/pdf/fssc04.pdf

Edkins, V. A. (2011). Defense attorney plea recommendations and client race: Does zealous representation apply equally to all? Law and Human Behavior, 35, 413-425. doi:10.1007/s10979-010-9254-0

Edwards v. Vannoy, 19-5807 $5^{\text {th }}$ Cir. (2020).

Friedman, H. (1972). Trial by jury: Criteria for convictions, jury size and type I and type II errors. The American Statistician, 26(2), 21-23. DOI: $10.1080 / 00031305.1972 .10477339$ Hayes, A.F. (2018). Introduction to mediation, moderation, and conditional process analysis: A regression-based approach (2 ${ }^{\text {nd }}$ ed.). New York, NY: Guilford Press.

Helm, R. K., Reyna, V. F., Franz, A. A., \& Novick, R. Z. (2018). Too young to plead? Risk, rationality, and plea bargaining's innocence problem in adolescents. Psychology, Public Policy, and Law, 24(2), 180-191. http://dx.doi.org.proxy.lib.pdx.edu/10.1037/law0000156

Hollander-Blumoff, R. (2008). Social psychology, information processing, and plea bargaining. 
PRE-PRINT Henderson, K. S. (forthcoming). Examining the Effect of Case and Trial Factors on Defense Attorneys' Plea Decision-making. Psychology, Crime \& Law. https://doi.org/10.1080/1068316X.2020.1805744

Marquette Law Review, 91(1), 163-182. Retrieved from http://scholarship.law.marquette.edu/cgi/viewcontent.cgi article=1131\&context=mulr

Johnson v. Louisiana, 406 U.S. 354 (1972).

Kaplan, A.B. \& Saack, A. (2016). Overturning Apodaca v. Oregon should be easy: Nonunanimous jury verdicts in criminal cases undermine the credibility of our justice system. Oregon Law Review, 95(1), 1-52.

Kerr, N. L., Atkin, R. S., Stasser, G., Meek, D., Holt, R. W., \& Davis, J. H. (1976). Guilt beyond a reasonable doubt: Effects of concept definition and assigned decision rule on the judgments of mock jurors. Journal of Personality and Social Psychology, 34(2), 282-294. doi:http://dx.doi.org.proxy.lib.pdx.edu/10.1037/0022-3514.34.2.282

Kramer, G. M., Wolbransky, M., \& Heilbrun, K. (2007). Plea bargaining recommendations by criminal defense attorneys: Evidence strength, potential sentence, and defendant preference. Behavioral Sciences and the Law, 25, 575-585. doi:10.1002/ bsl.759

Larsen, E. A. (2002). Specificity and juror agreement in civil cases. The University of Chicago Law Review, 69, 379- 401. Retrieved from https://chicagounbound.uchicago.edu/cgi/viewcontent.cgi? article=5131\&context=uclrev

McAllister, H. A., \& Bregman, N. J. (1986a). Plea bargaining by prosecutors and defense attorneys: A decision theory approach. Journal of Applied Psychology, 71, 686-690. doi:10.1037/0021- 9010.71.4.686

McAllister, H. A., \& Bregman, N. J. (1986b). Plea bargaining by defendants: A decision theory approach. The Journal of Social Psychology, 126(1), 105-110. https://doi.org/10.1080/00224545.1986.9713576

Mnookin, R. H., \& Kornhauser, L. (1979). Bargaining in the shadow of the law: The case of 
PRE-PRINT Henderson, K. S. (forthcoming). Examining the Effect of Case and Trial Factors on Defense Attorneys' Plea Decision-making. Psychology, Crime \& Law. https://doi.org/10.1080/1068316X.2020.1805744

divorce. Yale Law Journal, 88, 950-997. doi:10.2307/795824

Nemeth, C. (1977). Interactions between jurors as a function of majority vs. unanimity decision rules. Journal of Applied Social Psychology, 7(1), 38-56.

doi:http://dx.doi.org.proxy.lib.pdx.edu/10.1111/j.1559-1816.1977.tb02416.x

Oregon Office of Public Defense Services (2009). On the frequency of non-unanimous felony verdicts in Oregon. Retrieved from https://www.oregon.gov/OPDS/docs/Reports/PDSCReportNonUnanJuries.pdf

Pezdek, N. \& O'Brien, M. (2014). Plea bargaining and appraisals of eyewitness evidence by prosecutors and defense attorneys. Psychology, Crime, \& Law, 20(3), 222-241. http://dx.doi.org/10.1080/1068316X.2013.770855

Quick Facts Oregon. (2019, July 9). U.S. Census Bureau. Retrieved February 25, 2020, from https://www.census.gov/quickfacts/fact/table/OR/PST045219

Ramos v. Louisiana, No. 18-5924 (U.S. Apr. 20, 2020)

Redlich, A. D., Bushway, S. D., \& Norris, R. J. (2016). Plea decision-making by attorneys and judges. Journal of Experimental Criminology, 12, 537-561. doi:10.1007/s11292-0169264-0

Saks, M.J. \& Ostrom, T.M. (1975). Jury size and consensus requirements: The laws of probability vs. the laws of the land. Journal of Contemporary Law, 1, 163-173.

Selsky, A. (2018, Sept. 11). Labrador dog named Lucy saves Oregon man from sex conviction. Associated Press. Retrieved from https://www.apnews.com/34e672ffb06d4d229dbe21a52939bf0f 
PRE-PRINT Henderson, K. S. (forthcoming). Examining the Effect of Case and Trial Factors on Defense Attorneys' Plea Decision-making. Psychology, Crime \& Law. https://doi.org/10.1080/1068316X.2020.1805744

Swets, J., Dawes, R., \& Monahan, J. (2000). Psychological Science Can Improve Diagnostic Decisions. Psychological Science in the Public Interest, 1(1), 1-26. https://doiorg.proxy.lib.pdx.edu/10.1111/1529-1006.001

U.S. Department of Labor (2012). Labor force characteristics by race and ethnicity. Retrieved from https://www.bls.gov/opub/reports/race-andethnicity/archive/race_ethnicity_2011.pdf 
PRE-PRINT Henderson, K. S. (forthcoming). Examining the Effect of Case and Trial Factors on Defense Attorneys' Plea Decision-making. Psychology, Crime \& Law. https://doi.org/10.1080/1068316X.2020.1805744

Figure 1. Experiment One: Mediation model displaying the effects of jury verdict rule on plea decision mediated by likelihood of conviction at trial ratings.

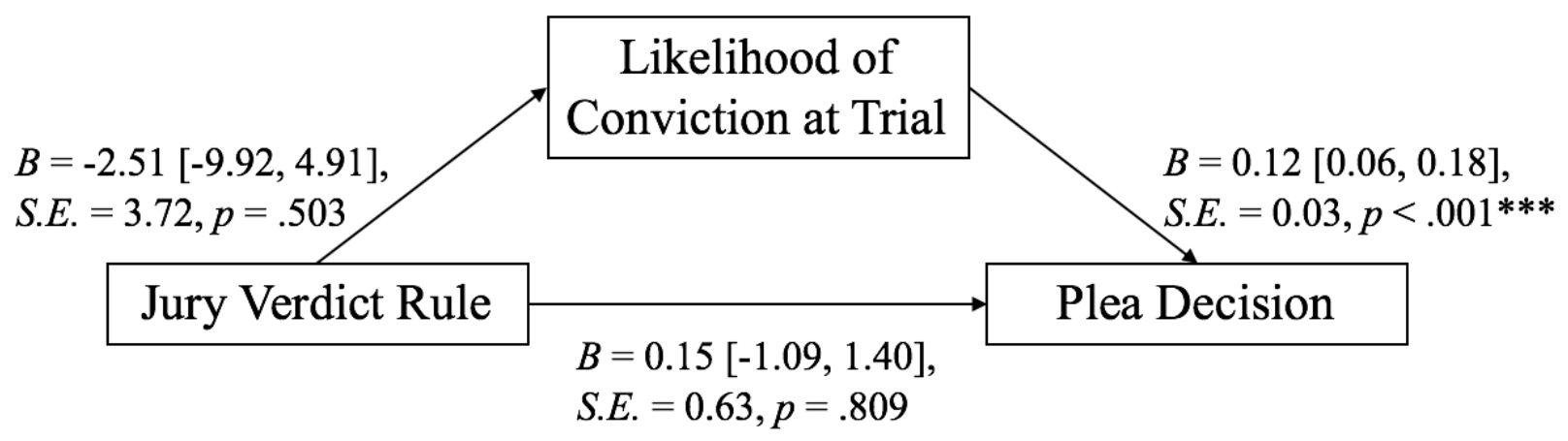

Note. Because likelihood of conviction was not an experimental manipulation, we conducted the same mediation model, but included appropriate covariates in the analysis $(\mathrm{C}=$ gender; $\mathrm{C}=$ years of experience, $\mathrm{C}=$ jurisdiction); the results did not change. 
PRE-PRINT Henderson, K. S. (forthcoming). Examining the Effect of Case and Trial Factors on Defense Attorneys' Plea Decision-making. Psychology, Crime \& Law.

https://doi.org/10.1080/1068316X.2020.1805744

Figure 2. Experiment One: Graph depicting the effect of defense attorneys' likelihood of conviction ratings on plea decisions (recommendations to client).

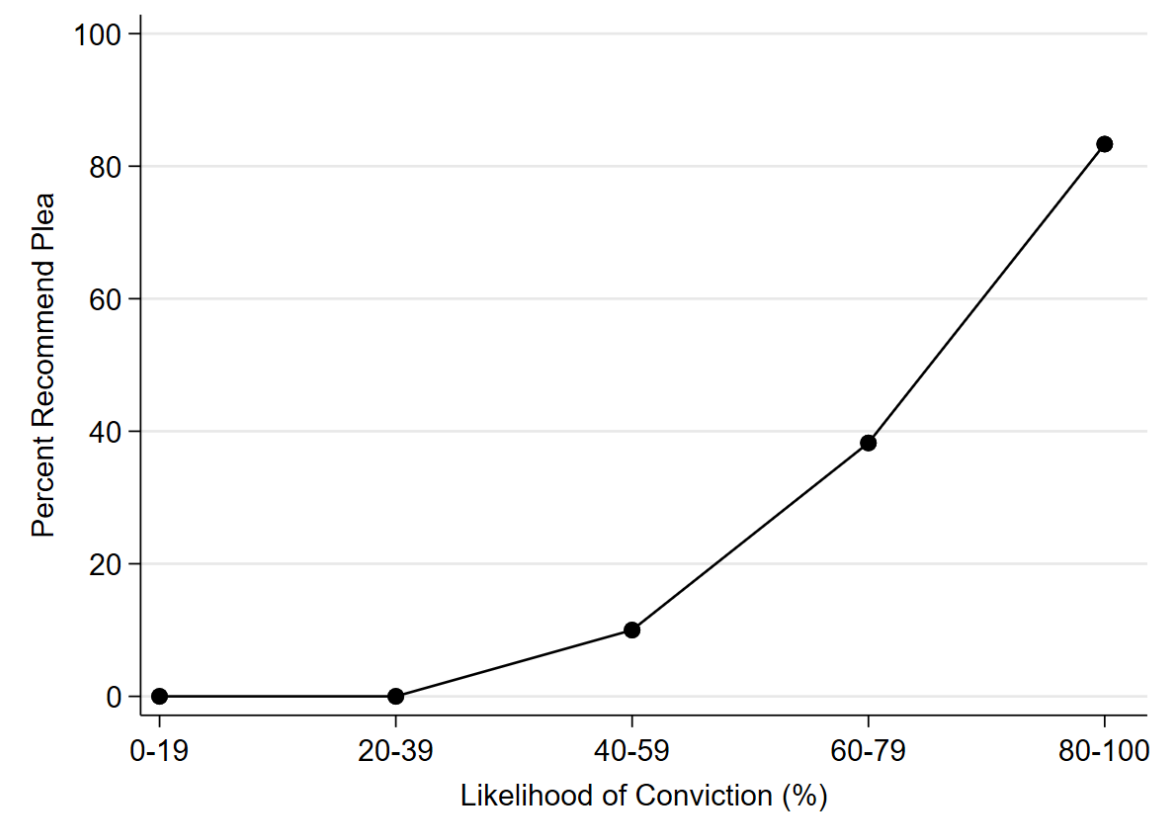

Note. Lowess (Locally Weighted Scatterplot Smoothing) tool was used to create this graph. 
PRE-PRINT Henderson, K. S. (forthcoming). Examining the Effect of Case and Trial Factors on Defense Attorneys' Plea Decision-making. Psychology, Crime \& Law.

https://doi.org/10.1080/1068316X.2020.1805744

Figure 3. Experiment One: Graph depicting the effect of defense attorneys' perception of their likelihood of winning on plea decisions (recommendations to client).

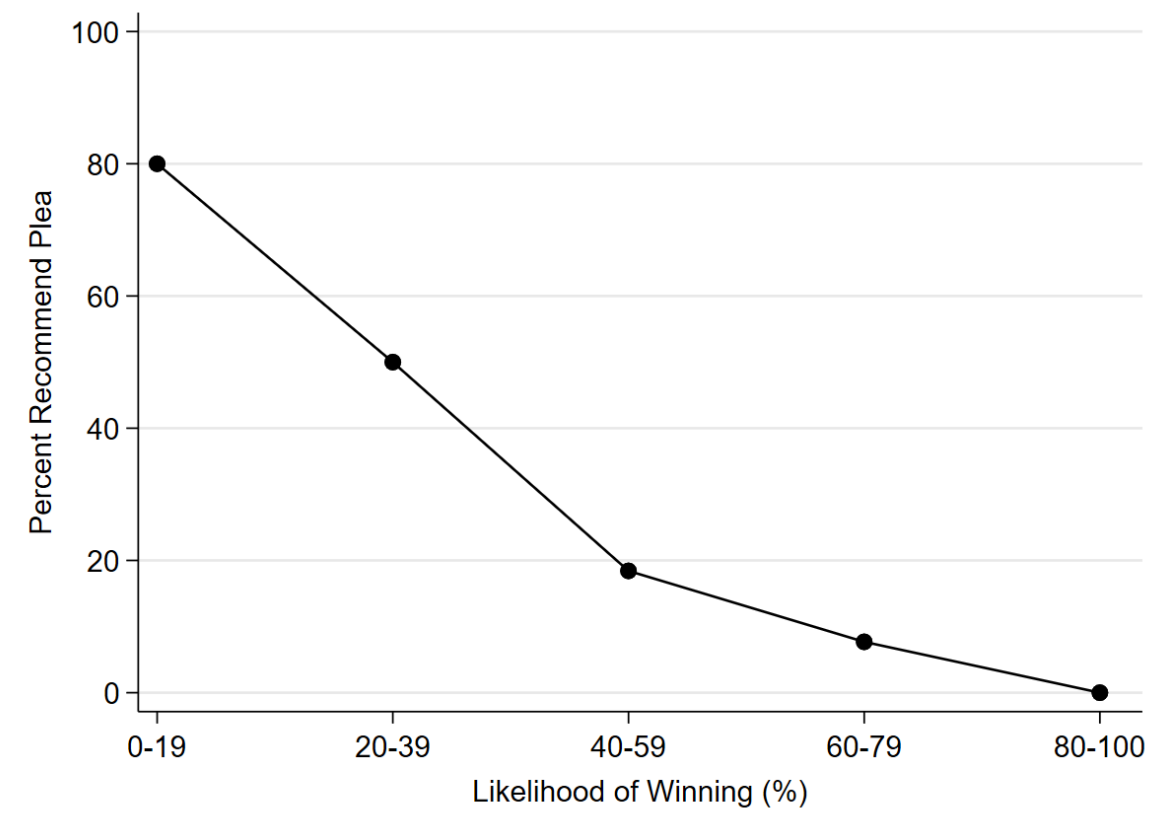

Note. Lowess (Locally Weighted Scatterplot Smoothing) tool was used to create this graph. 
PRE-PRINT Henderson, K. S. (forthcoming). Examining the Effect of Case and Trial Factors on Defense Attorneys' Plea Decisionmaking. Psychology, Crime \& Law. https://doi.org/10.1080/1068316X.2020.1805744

Table 1: Comprehensive Correlation Tables (DVs)

Experiment One

\begin{tabular}{|c|c|c|c|c|c|c|c|}
\hline & 1 & 2 & 3 & 4 & 5 & 6 & \\
\hline \multicolumn{8}{|l|}{ 1. Plea decision ${ }^{\mathrm{a}}$} \\
\hline 2. Defense willingness to plea & -.13 & - & & & & & \\
\hline 3. Prosecutor willingness to plea $^{b}$ & -.14 & .16 & - & & & & \\
\hline 4. Likelihood of conviction & $.55^{*}$ & -.03 & .07 & - & & & \\
\hline 5. Probability of winning at trial & $-.44 *$ & .19 & -.03 & $-.72 *$ & - & & \\
\hline 6. Highest plea offer (willing to accept) & $.32 *$ & .03 & -.03 & $.52 *$ & $-.51 *$ & - & \\
\hline 7. Average sentence $(\text { trial })^{\mathrm{b}}$ & -.05 & .12 & .09 & .12 & -.07 & $.38 *$ & \\
\hline \multicolumn{8}{|c|}{ Experiment Two } \\
\hline & 1 & 2 & 3 & 4 & 5 & 6 & 7 \\
\hline \multicolumn{8}{|l|}{ 1. Plea decision ${ }^{\mathrm{a}}$} \\
\hline 2. Defense willingness to plea & .10 & - & & & & & \\
\hline 3. Prosecutor willingness to plea $^{b}$ & .04 & .05 & - & & & & \\
\hline 4. Likelihood of conviction ${ }^{\mathrm{b}}$ & $.66^{*}$ & $.28^{*}$ & .06 & - & & & \\
\hline 5. Probability of winning at trial & $-.74 *$ & -.04 & -.11 & $-.70^{*}$ & - & & \\
\hline 6. Highest plea offer (willing to accept) & $.40^{*}$ & .20 & .12 & .23 & $-.51 *$ & - & \\
\hline 7. Average sentence (trial) & .05 & .10 & .01 & .07 & -.16 & $.63^{*}$ & - \\
\hline 8. Certainty of defendant's guilt ${ }^{\mathrm{b}}$ & $.27 *$ & .05 & -.03 & $.43 *$ & $-.31 *$ & .07 & -.05 \\
\hline
\end{tabular}

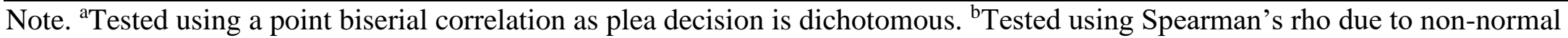
distribution. $* p<.05$. 
PRE-PRINT Henderson, K. S. (forthcoming). Examining the Effect of Case and Trial Factors on Defense Attorneys' Plea Decisionmaking. Psychology, Crime \& Law. https://doi.org/10.1080/1068316X.2020.1805744

Table 2. Experiment One: Summary of Full Regression Models

\begin{tabular}{|c|c|c|c|c|c|c|c|}
\hline & Plea decision $^{a}$ & $\begin{array}{c}\text { Defense } \\
\text { willingness to } \\
\text { plea }^{\mathrm{b}}\end{array}$ & $\begin{array}{c}\text { Prosecutor } \\
\text { willingness to } \\
\text { plea }^{\mathrm{b}}\end{array}$ & $\begin{array}{l}\text { Likelihood of } \\
\text { conviction }^{\mathrm{b}}\end{array}$ & $\begin{array}{l}\text { Probability of } \\
\text { winning at trial }\end{array}$ & $\begin{array}{l}\text { Highest plea } \\
\text { offer }^{\mathrm{b}}\end{array}$ & $\begin{array}{c}\text { Average } \\
\text { sentence }(\text { trial })^{\mathrm{b}}\end{array}$ \\
\hline & $\operatorname{Exp}(B)$ & & & $B,[95 \% C I], S E$ & & & \\
\hline Verdict rule & $\begin{array}{c}0.93 \\
{[0.32,2.76]} \\
0.55\end{array}$ & $\begin{array}{c}1.90 \\
{[-11.53,15.34]} \\
6.72 \\
\end{array}$ & $\begin{array}{c}4.89 \\
{[-2.83,12.61]} \\
3.87\end{array}$ & $\begin{array}{c}-3.90 \\
{[-12.03,4.22]} \\
4.07\end{array}$ & $\begin{array}{c}2.31 \\
{[-5.92,10.54]} \\
4.12\end{array}$ & $\begin{array}{c}-4.62 \\
{[-19.39,10.15]} \\
7.39\end{array}$ & $\begin{array}{c}-5.87 \\
{[-16.04,4.29]} \\
5.09\end{array}$ \\
\hline $\begin{array}{l}\text { Male } \\
\text { (ref: female) }\end{array}$ & $\begin{array}{c}1.31 \\
{[0.39,4.43]} \\
0.62\end{array}$ & $\begin{array}{c}-5.74 \\
{[-20.33,8.85]} \\
7.30\end{array}$ & $\begin{array}{c}3.14 \\
{[-5.27,11.56]} \\
4.22\end{array}$ & $\begin{array}{c}2.70 \\
{[-6.24,11.63]} \\
4.48\end{array}$ & $\begin{array}{c}-8.43 \\
{[-17.49,0.62]} \\
4.54\end{array}$ & $\begin{array}{c}-4.22 \\
{[-20.25,11.80]} \\
8.02\end{array}$ & $\begin{array}{c}-0.76 \\
{[-11.94,10.42]} \\
5.60\end{array}$ \\
\hline $\begin{array}{l}\text { Rural } \\
\text { (ref: urban) }\end{array}$ & $\begin{array}{c}1.16 \\
{[0.36,3.77]} \\
0.60\end{array}$ & $\begin{array}{c}-0.83 \\
{[-15.82,14.16]} \\
7.50\end{array}$ & $\begin{array}{c}1.33 \\
{[-7.26,9.91]} \\
4.30\end{array}$ & $\begin{array}{c}1.72 \\
{[-7.25,10.69]} \\
4.49\end{array}$ & $\begin{array}{c}0.88 \\
{[-8.21,9.98]} \\
4.55\end{array}$ & $\begin{array}{c}5.18 \\
{[-11.31,21.68]} \\
8.25\end{array}$ & $\begin{array}{c}11.84 * \\
{[0.49,23.19]} \\
5.69\end{array}$ \\
\hline $\begin{array}{l}\text { Neither } \\
\text { (ref: urban) }\end{array}$ & $\begin{array}{c}0.98 \\
{[0.20,4.71]} \\
0.80\end{array}$ & $\begin{array}{c}-5.03 \\
{[-22.81,12.74]} \\
8.89\end{array}$ & $\begin{array}{c}5.10 \\
{[-5.47,15.66]} \\
5.29\end{array}$ & $\begin{array}{c}1.87 \\
{[-9.57,13.31]} \\
5.73\end{array}$ & $\begin{array}{c}-1.65 \\
{[13.24,9.94]} \\
5.81\end{array}$ & $\begin{array}{c}11.15 \\
{[-9.13,31.44]} \\
10.15\end{array}$ & $\begin{array}{c}1.53 \\
{[-12.32,15.38]} \\
6.93\end{array}$ \\
\hline $\begin{array}{l}\text { Experience } \\
\text { (years) }\end{array}$ & $\begin{array}{c}1.01 \\
{[0.97,1.05]} \\
0.02\end{array}$ & $\begin{array}{c}-0.08 \\
{[-0.60,0.44]} \\
.26\end{array}$ & $\begin{array}{c}-0.31 * \\
{[-0.62,-0.01]} \\
.15\end{array}$ & $\begin{array}{c}-0.06 \\
{[-0.38,0.26]} \\
0.16\end{array}$ & $\begin{array}{c}-0.05 \\
{[0.37,0.27]} \\
0.16\end{array}$ & $\begin{array}{c}0.18 \\
{[-0.39,0.75]} \\
0.29\end{array}$ & $\begin{array}{c}0.45^{*} \\
{[0.05,0.86]} \\
0.20\end{array}$ \\
\hline Constant & $\begin{array}{c}0.24 \\
{[-0.06,1.05]} \\
0.18\end{array}$ & $\begin{array}{c}49.64 \\
{[32.14,67.15]} \\
8.76\end{array}$ & $\begin{array}{c}86.45 \\
{[76.28,96.62]} \\
5.10\end{array}$ & $\begin{array}{c}56.85 \\
{[46.08,67.63]} \\
5.40\end{array}$ & $\begin{array}{c}51.42 \\
{[40.50,62.33]} \\
5.47\end{array}$ & $\begin{array}{c}53.02 \\
{[33.95,72.08]} \\
9.54\end{array}$ & $\begin{array}{c}88.61 \\
{[75.29,101.94]} \\
6.67\end{array}$ \\
\hline
\end{tabular}

Note. Plea decision is dichotomous (accept guilty plea versus go to trial). Defense willingness to plea, prosecutor willingness to plea, likelihood of conviction, and probability of winning at trial are scales ranging from $0-100 \%$. Highest plea offer and average sentence were open ended response in number of months. ${ }^{a}$ Tested using a logistic regression model. ${ }^{\mathrm{b}}$ Tested using OLS regression models. $* p<.05$. 
PRE-PRINT Henderson, K. S. (forthcoming). Examining the Effect of Case and Trial Factors on Defense Attorneys' Plea Decisionmaking. Psychology, Crime \& Law. https://doi.org/10.1080/1068316X.2020.1805744

Table 3. Experiment One: Means and Percentage Agreement with Statements regarding Jury Verdict Rules

\begin{tabular}{|c|c|c|c|c|}
\hline Item & $N$ & $M(S D)$ & $\begin{array}{c}\text { Somewhat- } \\
\text { Strongly } \\
\text { Disagree }\end{array}$ & $\begin{array}{c}\text { Somewhat- } \\
\text { Strongly } \\
\text { Agree }\end{array}$ \\
\hline $\begin{array}{l}\text { It is easier to get a conviction with a unanimous verdict rule than a non- } \\
\text { unanimous }\end{array}$ & 80 & $1.85(1.22)$ & $91.3 \%$ & $8.8 \% \%$ \\
\hline $\begin{array}{l}\text { Convincing a unanimous jury will be more difficult than convincing a non- } \\
\text { unanimous jury }\end{array}$ & 80 & $4.36(1.53)$ & $23.9 \%$ & $76.4 \%$ \\
\hline $\begin{array}{l}\text { Non-unanimous jury rules undermine the requirement that guilt be proven } \\
\text { beyond a reasonable doubt }\end{array}$ & 81 & $5.40(1.09)$ & $7.4 \%$ & $92.5 \%$ \\
\hline Non-unanimous verdict rules create a greater risk for wrongful conviction & 81 & $5.44(1.06)$ & $6.1 \%$ & $93.8 \%$ \\
\hline Non-unanimous verdict rules harm minorities in the criminal justice system & 81 & $5.36(1.17)$ & $11.1 \%$ & $88.9 \%$ \\
\hline $\begin{array}{l}\text { Hung juries are more likely to occur with a unanimous jury than majority } \\
\text { rule jury }\end{array}$ & 81 & $4.49(1.17)$ & $16 \%$ & $84 \%$ \\
\hline
\end{tabular}

Note. Agreement with statements ranged from 1- "strongly disagree" to 6- "strongly agree". Percentages collapsed to demonstrate trends between somewhat-strongly agree[disagree]. Percentages might not add to $100 \%$ due to rounding. 
PRE-PRINT Henderson, K. S. (forthcoming). Examining the Effect of Case and Trial Factors on Defense Attorneys' Plea Decisionmaking. Psychology, Crime \& Law. https://doi.org/10.1080/1068316X.2020.1805744

Table 4. Experiment One: Summary of Qualitative Responses Regarding Plea Decision-making

"If the jury verdict rule were unanimous, rather than majority, do you think that would influence defendants' plea decision-making? How so?"

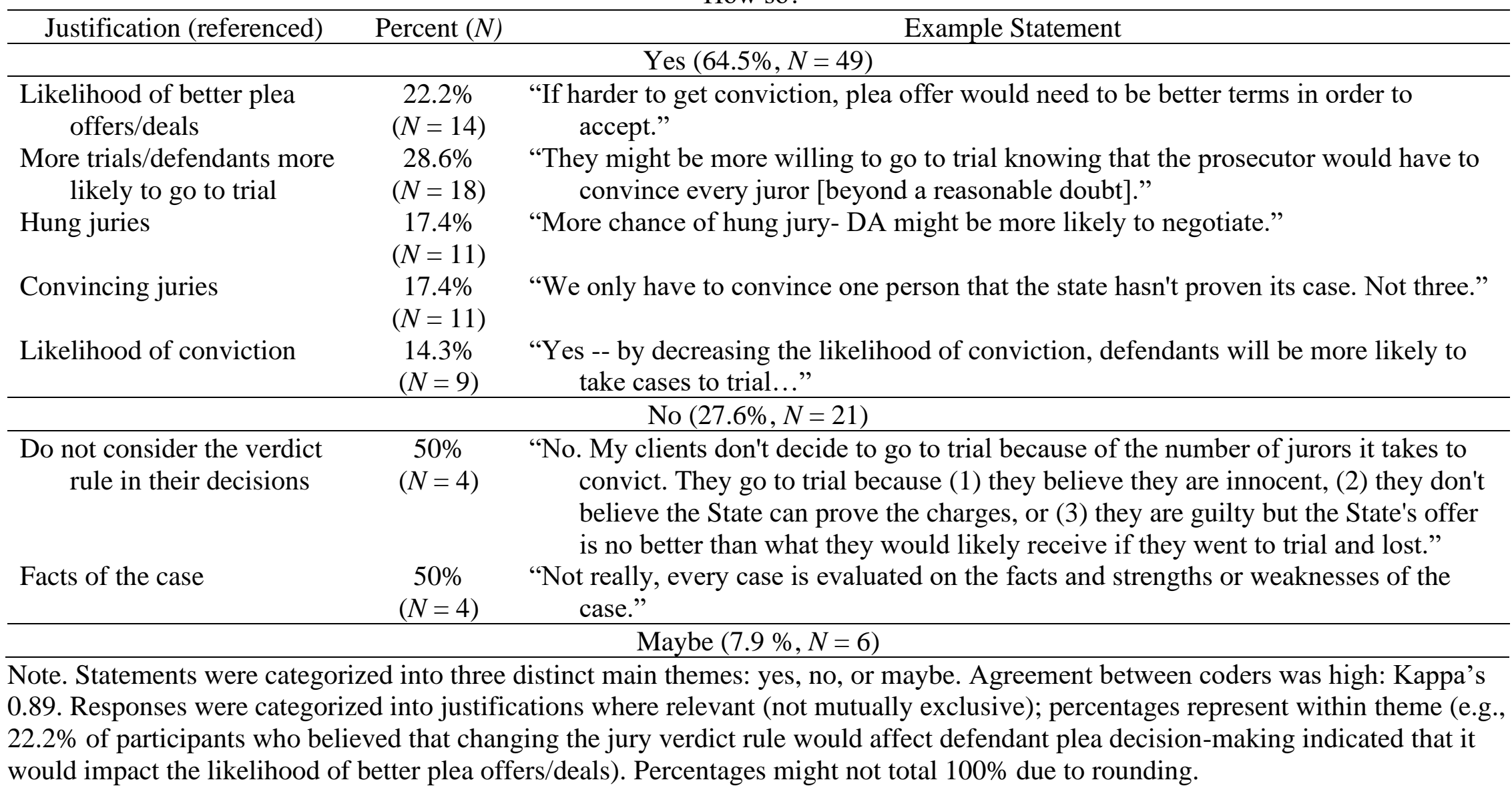


PRE-PRINT Henderson, K. S. (forthcoming). Examining the Effect of Case and Trial Factors on Defense Attorneys' Plea Decisionmaking. Psychology, Crime \& Law. https://doi.org/10.1080/1068316X.2020.1805744

Table 5. Experiment One: Summary of Qualitative Responses Regarding Case Strategy

"If the verdict decision rule were unanimous, rather than majority, would it affect how you handle cases? How so?"

\begin{tabular}{|c|c|c|}
\hline Justification (referenced) & Percent $(N)$ & Example Statement \\
\hline \multicolumn{3}{|r|}{ Yes $(60.8 \%, N=45)$} \\
\hline $\begin{array}{l}\text { Likelihood of better plea } \\
\text { offers/deals }\end{array}$ & $\begin{array}{l}16.7 \% \\
(N=9)\end{array}$ & "Leverage on the DA for much better deal depending on facts." \\
\hline $\begin{array}{l}\text { Convincing juries/threshold } \\
\text { for conviction higher }\end{array}$ & $\begin{array}{c}13 \% \\
(N=7)\end{array}$ & $\begin{array}{l}\text { "Yes, I would adopt more trial strategies designed to convince a few of the jurors to } \\
\text { agree with me as opposed to attempting to convince all jurors in some cases." }\end{array}$ \\
\hline Hung juries & $\begin{array}{l}7.4 \% \\
(N=4)\end{array}$ & $\begin{array}{l}\text { "... I would advise clients of the greater likelihood of a longer process resulting from } \\
\text { more hung juries..." }\end{array}$ \\
\hline $\begin{array}{l}\text { Increase willingness to go to } \\
\text { trial }\end{array}$ & $\begin{array}{c}40.7 \% \\
(N=22)\end{array}$ & $\begin{array}{l}\text { "A unanimous jury rule would make it more likely for me to recommend that clients } \\
\text { seek trial..." }\end{array}$ \\
\hline $\begin{array}{l}\text { State might not believe they } \\
\text { have as strong of a } \\
\text { chance of winning }\end{array}$ & $\begin{array}{c}5.5 \% \\
(N=3)\end{array}$ & $\begin{array}{l}\text { "...What the unanimous rule would really do is make DA's more uncomfortable... } \\
\text { would remove some comfort and a built-in advantage for the DA." }\end{array}$ \\
\hline $\begin{array}{l}\text { Would affect trial strategy, } \\
\text { not assessment of case }\end{array}$ & $\begin{array}{l}9.3 \% \\
(N=5)\end{array}$ & "It would change arguments and jury selection." \\
\hline $\begin{array}{l}\text { Would discuss verdict rule } \\
\text { with client }\end{array}$ & $\begin{array}{l}7.4 \% \\
(N=4)\end{array}$ & $\begin{array}{l}\text { "...I'd never have to explain to a client again how they could be found guilty when } \\
\text { two people voted not guilty." }\end{array}$ \\
\hline \multicolumn{3}{|r|}{ No $(33.8 \%, N=25)$} \\
\hline $\begin{array}{l}\text { Facts of case and whether } \\
\text { it's "triable" }\end{array}$ & $\begin{array}{c}60 \% \\
(N=3)\end{array}$ & "Probably not. Cases are generally triable or not triable." \\
\hline $\begin{array}{l}\text { Do not consider the verdict } \\
\text { rule in their decisions }\end{array}$ & $\begin{array}{c}40 \% \\
(N=2)\end{array}$ & $\begin{array}{l}\text { "No. I don't advise clients to go to trial because of the number of jurors it takes to } \\
\text { convict. I base my advice on the strengths and weakness of their case, and } \\
\text { whether the State's offer is reasonable in light of what they would likely receive } \\
\text { from the judge if convicted." }\end{array}$ \\
\hline \multicolumn{3}{|r|}{ Maybe $(5.4 \%, N=4)$} \\
\hline
\end{tabular}

Note. Statements were categorized into three distinct main themes: yes, no, or maybe. Agreement between coders was high: Kappa's = .88. Responses were categorized into justifications where relevant (not mutually exclusive); percentages represent within theme (e.g., $16.7 \%$ of participants who believed that changing the jury verdict rule would affect how they handle cases indicated that it would impact the likelihood of better plea offers/deals). Percentages might not total $100 \%$ due to rounding. 
PRE-PRINT Henderson, K. S. (forthcoming). Examining the Effect of Case and Trial Factors on Defense Attorneys' Plea Decisionmaking. Psychology, Crime \& Law. https://doi.org/10.1080/1068316X.2020.1805744

Table 6. Experiment Two: Summary of Full Regression Models

\begin{tabular}{|c|c|c|c|c|c|c|c|c|}
\hline & Plea decision $^{\mathrm{a}}$ & $\begin{array}{c}\text { Defense } \\
\text { willingness to } \\
\text { plea }^{\mathrm{b}}\end{array}$ & $\begin{array}{c}\text { Prosecutor } \\
\text { willingness to } \\
\text { plea }^{\mathrm{b}} \\
\end{array}$ & $\begin{array}{l}\text { Likelihood of } \\
\text { conviction }^{\mathrm{b}}\end{array}$ & 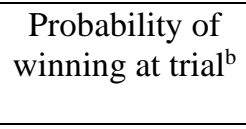 & $\begin{array}{l}\text { Highest plea } \\
\text { offer }^{b}\end{array}$ & $\begin{array}{c}\text { Average } \\
\text { sentence } \\
{(\text { trial })^{b}}\end{array}$ & $\begin{array}{l}\text { Accused's } \\
\text { guilt }^{\mathrm{b}}\end{array}$ \\
\hline & $\operatorname{Exp}(B)$ & \multicolumn{7}{|c|}{$B,[95 \% C I], S E$} \\
\hline Verdict rule & $\begin{array}{c}0.27 \\
{[0.07,1.10]} \\
0.71\end{array}$ & $\begin{array}{c}-7.49 \\
{[-21.67,6.70]} \\
7.09\end{array}$ & $\begin{array}{c}6.53 \\
{[-2.18,15.24]} \\
4.36\end{array}$ & $\begin{array}{c}-2.01 \\
{[-10.23,6.20]} \\
4.11\end{array}$ & $\begin{array}{c}4.33 \\
{[-4.34,13.00]} \\
4.34\end{array}$ & $\begin{array}{c}-2.16 \\
{[-5.33,1.01]} \\
1.59\end{array}$ & $\begin{array}{c}-2.81 \\
{[-5.92,0.30]} \\
1.55\end{array}$ & $\begin{array}{c}-0.19 \\
{[-0.57,19]} \\
0.19\end{array}$ \\
\hline $\begin{array}{l}\text { Strength of } \\
\text { Evidence }\end{array}$ & $\begin{array}{c}11.15^{*} \\
{[2.19,56.90]} \\
0.83\end{array}$ & $\begin{array}{c}6.12 \\
{[-8.36,20.61]} \\
7.24\end{array}$ & $\begin{array}{c}2.38 \\
{[-6.56,11.33]} \\
4.47\end{array}$ & $\begin{array}{c}18.93 * \\
{[10.52,27.35]} \\
4.21\end{array}$ & $\begin{array}{c}-19.19^{*} \\
{[-28.10,10.29]} \\
4.46\end{array}$ & $\begin{array}{c}4.43^{*} \\
{[1.24,7.62]} \\
1.60\end{array}$ & $\begin{array}{c}2.60 \\
{[-0.52,5.72]} \\
1.56\end{array}$ & $\begin{array}{c}0.29 \\
{[-0.09,0.66]} \\
0.19\end{array}$ \\
\hline $\begin{array}{l}\text { Male } \\
\text { (ref: female) }\end{array}$ & $\begin{array}{c}0.36 \\
{[0.08,1.70]} \\
0.80\end{array}$ & $\begin{array}{c}-7.32 \\
{[-23.62,8.97]} \\
8.15\end{array}$ & $\begin{array}{c}9.36 \\
{[-0.51,19.23]} \\
4.94\end{array}$ & $\begin{array}{c}-4.46 \\
{[-13.79,4.88]} \\
4.67\end{array}$ & $\begin{array}{c}6.46 \\
{[-3.52,16.44]} \\
4.99\end{array}$ & $\begin{array}{c}-2.57 \\
{[-6.04,0.90]} \\
1.73\end{array}$ & $\begin{array}{c}-0.60 \\
{[-4.11,2.91]} \\
1.76\end{array}$ & $\begin{array}{c}0.00 \\
{[-0.41,0.42]} \\
0.21\end{array}$ \\
\hline $\begin{array}{l}\text { Rural } \\
\text { (ref: urban) }\end{array}$ & $\begin{array}{c}0.46 \\
{[0.11,1.98]} \\
0.75 \\
\end{array}$ & $\begin{array}{c}-2.12 \\
{[-18.34,14.09]} \\
8.11 \\
\end{array}$ & $\begin{array}{c}-4.23 \\
{[-14.35,5.88]} \\
5.06\end{array}$ & $\begin{array}{c}-4.24 \\
{[-13.64,5.17]} \\
4.71 \\
\end{array}$ & $\begin{array}{c}2.52 \\
{[-7.38,12.41]} \\
4.95 \\
\end{array}$ & $\begin{array}{c}1.63 \\
{[-2.02,5.27]} \\
1.82 \\
\end{array}$ & $\begin{array}{c}0.07 \\
{[-3.54,3.67]} \\
1.80 \\
\end{array}$ & $\begin{array}{c}-0.03 \\
{[-0.47,0.40]} \\
0.22 \\
\end{array}$ \\
\hline $\begin{array}{l}\text { Neither } \\
\text { (ref: urban) }\end{array}$ & $\begin{array}{c}0.45 \\
{[0.09,2.26]} \\
0.82 \\
\end{array}$ & $\begin{array}{c}-13.76 \\
{[-32.40,4.89]} \\
9.32 \\
\end{array}$ & $\begin{array}{c}-0.96 \\
{[-12.38,10.46]} \\
5.71 \\
\end{array}$ & $\begin{array}{c}-0.62 \\
{[-11.44,10.21]} \\
5.42 \\
\end{array}$ & $\begin{array}{c}-1.47 \\
{[-12.86,9.92]} \\
5.70\end{array}$ & $\begin{array}{c}-2.30 \\
{[-6.43,1.84]} \\
2.07 \\
\end{array}$ & $\begin{array}{c}-2.73 \\
{[-6.73,1.28]} \\
2.00\end{array}$ & $\begin{array}{c}-0.19 \\
{[-0.67,0.29]} \\
0.24\end{array}$ \\
\hline $\begin{array}{l}\text { Experience } \\
\text { (years) }\end{array}$ & $\begin{array}{c}1.05 \\
{[1.00,1.11]} \\
0.03\end{array}$ & $\begin{array}{c}0.28 \\
{[-0.31,0.87]} \\
0.29\end{array}$ & $\begin{array}{c}-0.20 \\
{[-0.57,0.17]} \\
0.18\end{array}$ & $\begin{array}{c}0.38^{*} \\
{[0.04,0.72]} \\
0.17\end{array}$ & $\begin{array}{c}-0.45^{*} \\
{[-0.81,-0.09]} \\
0.18\end{array}$ & $\begin{array}{c}-0.12 \\
{[-0.24,0.01]} \\
0.06\end{array}$ & $\begin{array}{c}-0.03 \\
{[-0.15,0.09]} \\
0.06\end{array}$ & $\begin{array}{c}0.01 \\
{[-0.01,0.03]} \\
0.01\end{array}$ \\
\hline Constant & $\begin{array}{c}4.42 \\
{[0.64,30.65]} \\
0.99\end{array}$ & $\begin{array}{c}57.53 \\
{[35.12,79.93]} \\
11.20\end{array}$ & $\begin{array}{c}81.16 \\
{[67.81,94.51]} \\
6.68\end{array}$ & $\begin{array}{c}69.37 \\
{[56.71,82.03]} \\
6.33\end{array}$ & $\begin{array}{c}35.93 \\
{[22.55,49.31]} \\
6.70\end{array}$ & $\begin{array}{c}12.23 \\
{[7.47,16.99]} \\
2.38\end{array}$ & $\begin{array}{c}14.79 \\
{[9.94,19.64]} \\
2.43\end{array}$ & $\begin{array}{c}3.63 \\
{[3.05,4.21]} \\
0.29\end{array}$ \\
\hline
\end{tabular}

Note. Plea decision is dichotomous (accept guilty plea versus go to trial). Defense willingness to plea, prosecutor willingness to plea, likelihood of conviction, and probability of winning at trial are scales ranging from 0-100\%. Highest plea offer and average sentence were open ended response in number of months.

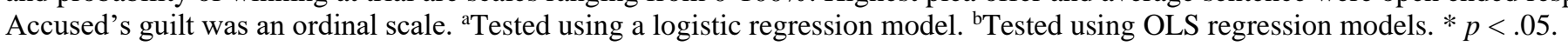

